\title{
Structure and Evolution of Deeply Developed Convective Cells in a Long- Lived Cumulonimbus Cloud under a Weak Vertical Wind-Shear Condition
}

\author{
Yukari SHUSSE, Kazuhisa TSUBOKI, Biao GENG1', Haruya MINDA, \\ and \\ Takao TAKEDA ${ }^{2}$ \\ Hydrospheric Atmospheric Research Center, Nagoya University, Nagoya, Japan
}

(Manuscript received 27 November 2001, in final form 28 February 2005)

\begin{abstract}
The structure and evolution of deeply developed convective cells within a long-lived multicellular cumulonimbus cloud that developed over the Huaihe River Basin in China on 13 July 1998 during the GAME/HUBEX were studied, mainly using the observational data of Doppler radars. The lifetime of the cumulonimbus cloud was longer than 3.5 hours, and its maximum echo-top height was $19 \mathrm{~km}$ AGL. The atmospheric condition was characterized by a large CAPE $\left(2300 \mathrm{~J} \mathrm{~kg}^{-1}\right)$, and weak vertical wind shear $\left(1.6 \mathrm{~m} \mathrm{~s}^{-1} \mathrm{~km}^{-1}\right.$ toward the north-northeast below $\left.5 \mathrm{~km} \mathrm{AGL}\right)$.

In the mature stage of the cloud, a large radar-echo region stronger than $40 \mathrm{dBZ}$ was observed. It was almost upright, and showed almost the same horizontal areas between 5 and $15 \mathrm{~km}$ AGL. Two strong updrafts existed around the upshear and downshear parts of the strong echo region, and they tilted toward the downshear and upshear sides, respectively. A downdraft developed in the eastern part of the cloud, where a cell-relative northeasterly wind was present at the low and middle levels; however, the wind was not observed in the synoptic-scale environment. The downdraft was located between the two updrafts. A descending northeasterly airflow continuously lifted the low-level air coming into the upshear-side updraft from the southwestern (upshear) side. The downdraft, and its surface outflow, did not cut off the supply of low-level air coming into the downshear-side updraft from the northern (downshear) side. The vigorous development of the cumulonimbus cloud in the mature stage was caused by the development of these adjacent convective cells. Significant processes in the formation of the mature structure are the maintenance of the upshear-side convective cell, and the change of the downshear-side updraft from downshear-tilting to upshear-tilting in association with the intensification of the downdraft in the cell-relative northeasterly wind.
\end{abstract}

Corresponding author and present affiliation: Yukari Shusse, Okinawa Subtropical Environment Remote Sensing Center, National Institute of Information and Communications Technology, Okinawa, 904-0411, Japan.

E-mail: shusse@nict.go.jp

1 Present affiliation: Institute of observational Research for Global Change, Yokosuka, Japan.

2 Present affiliation: Nagoya University, Nagoya, 464-8601, Japan.

(C) 2005, Meteorological Society of Japan

\section{Introduction}

Some previous studies based on observations in Japan (e.g., Takeda and Imai 1976), the tropics (e.g., Warner et al. 1980), south Florida (e.g., Simpson et al. 1980), and the Great Plains (e.g., Bluestein and Parker 1993) have shown that only a few cumulonimbus clouds develop much deeper than many other cumulonimbus clouds in an identical synoptic atmospheric situation. These studies indicate that environ- 
mental condition is not the only determinant of the structure and evolution of cumulonimbus clouds. To understand the behavior of a cumulonimbus cloud in the atmosphere, it is indispensable to investigate the process of the selective development of a few cumulonimbus clouds among many clouds in an identical synoptic atmosphere. Here, the term "cumulonimbus cloud" is used to refer to the overall aggregate of convective precipitating cells.

It has been well established (e.g., Klemp and Wilhelmson 1978a, b; Wilhelmson and Klemp 1978; Weisman and Klemp 1982) that vertical wind shear and convective available potential energy (CAPE) of the environmental atmosphere are important factors for the structure and evolution of cumulonimbus clouds, and that strong vertical shear is a necessary condition for their organization. Many observational and numerical studies examining deeply developed cumulonimbus clouds have focused on the structure and evolution of super-cellular or organized multi-cellular cumulonimbus clouds. These studies have demonstrated a considerable knowledge of the relationship between the steady-state structure and dynamics of organized cumulonimbus clouds, and an environmental atmospheric condition. However, this knowledge does not satisfactorily explain how only a few clouds of many are organized, or achieve a favorable structure for deep development in an identical synoptic situation.

Some numerical studies have shown the structure and evolution of cumulonimbus clouds resulting from a local modification of the ambient atmosphere, which is caused by adjacent clouds or precipitating cells. For example, Droegemeier and Wilhelmson (1985a, b) and Tao and Simpson $(1984,1989)$ showed that the interaction of surface downdraft-outflows from pre-existing adjacent precipitating clouds is important to promote the generation and merging of clouds. Misumi et al. (1994) showed the formation process of a long-lasting convective cloud under the influence of low-level cold outflow from adjacent short-lived cells. These studies imply that the local modification of the ambient atmosphere is one of the crucial factors for the selective development, or organization, of a few cumulonimbus clouds among many clouds in an identical synoptic situation. A detailed investigation of the evolution of $\mathrm{cu}-$ mulonimbus clouds is required to understand these developmental processes.

A limited number of observational studies examined the detailed evolution of cumulonimbus clouds. Fujiyoshi and Geng (1995) reported the structure and evolution of a small rainband in the tropics. In the rainband, there were no strong downdrafts below the heavy rainfall area, and there was no widespread stratiform region behind the convective region. However, a convective cell showed explosive development in the mature stage of the rainband. The aggregation of convective-scale rear inflows within the rainband, which caused strong low-level convergence, was important in the deep development of the rainband. Geng et al. (1997) examined the evolution of a multicellular cumulonimbus cloud, and found that the mid-level rear inflow to the cloud was enhanced by a mid-level vortex within an adjacent cumulonimbus cloud. In the mature stage, cells developed strongly above merged outflows from a downdraft in an inflow region of midlevel environmental air, a downdraft which intensified in the mid-level rear inflow region, and the descending mid-level rear inflow. These studies suggested that the structure and evolution of covective cells within a cloud under a local modification of the ambient atmosphere were very important for the selective development of cumulonimbus clouds.

In a region far south of the Meiyu front of eastern China, deep cumulonimbus clouds develop frequently, even though the large-scale convergence is weak under the Pacific subtropical high (Kato et al. 1995; Shinoda and Uyeda 2002). Few studies have documented the behavior of deep cumulonimbus clouds and convective cells in this region, because adequate observational data, especially threedimensional airflow data, are very scarce for the description of the evolution of cumulonimbus clouds. This paper presents a case study of a multicellular cumulonimbus cloud observed by three Doppler radars on 13 July 1998, in the Huaihe River Basin of China, during the Intensive Field Observation (IFO) of GAME/HUBEX (the GEWEX Asian Monsoon Experiment/Huaihe River Basin Experiment). The cumulonimbus cloud developed exceptionally, among 15 cumulonimbus clouds on this day, in an environmental atmosphere of weak 


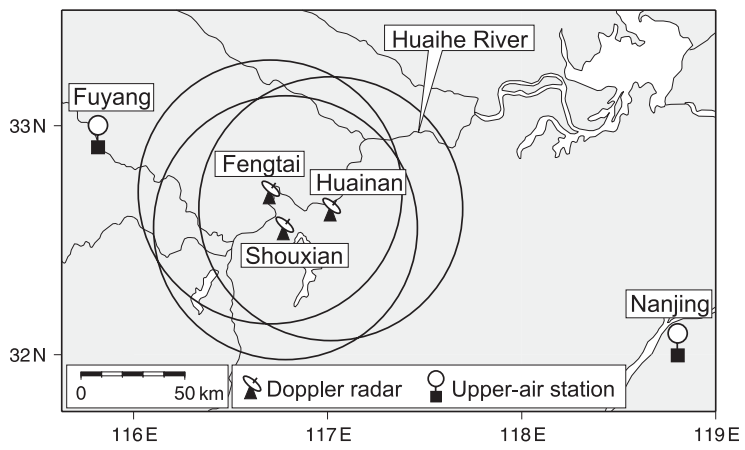

Fig. 1. Doppler-radar observation sites and upper-air sounding stations. The circles show the observation ranges of Doppler radars. The location of the map region is shown in Fig. 2.

vertical wind shear and large CAPE. The cloud lasted for at least 3.5 hours, with the highest echo top of $19 \mathrm{~km}$. The purpose of this study is to describe the detailed three-dimensional evolution of deeply developed convective cells, within a long-lived cumulonimbus cloud from its early development to maturity, and to discuss how favorable the structures of the convective cells are for the deep development of the cumulonimbus cloud.

\section{Data}

The GAME/HUBEX IFO was carried out in June and July 1998 in the Huaihe River Basin, and its surrounding area in China. Three Xband Doppler radars were operated during the IFO. Two Doppler radars of Nagoya University were installed at Shouxian and Fengtai, and a Doppler radar of Hokkaido University was installed at Huainan, as shown in Fig. 1. The maximum quantitative observation range of each Doppler radar was $64 \mathrm{~km}$. The sampling resolution of radar data was $250 \mathrm{~m}$ in the direction of the radar beam, and 1 degree in the direction of the azimuth. One volume scan was made with 14 elevation angles, from $0.5^{\circ}$ to $41^{\circ}$ in 7 minutes.

Radar reflectivity data of the Shouxian radar were used to examine the structure and evolution of radar echoes in this paper. The Huainan radar data were also used, to derive threedimensional wind fields. Data of the Fengtai radar were not used since they were not available to accurately estimate the threedimensional wind field for this analysis.

Doppler velocities and radar reflectivity factors were interpolated at grid points with vertical and horizontal intervals of $500 \mathrm{~m}$ in Cartesian coordinates, using the Cressman weighting function (Cressman 1959). A correction related to the movement of radar echoes was made, using Gal-Chen's method (Gal-Chen 1982). The horizontal velocity was derived in the region where the intersecting angle of radar beams is from $20^{\circ}$ to $160^{\circ}$. The vertical velocity was calculated only by the upward integration of the anelastic continuity equation, with the boundary condition of $0 \mathrm{~m} \mathrm{~s}^{-1}$ at the ground surface, because data at upper levels were scarce around the echo top and the boundary condition of $0 \mathrm{~m} \mathrm{~s}^{-1}$ at the echo top was not applied. By this method, a calculation error in the vertical velocity becomes large in the upper levels. In this paper, therefore, only airflows below $10 \mathrm{~km}$ above ground level (AGL) are shown, and the airflow structure is described focusing on the low and middle levels. The middle time of each volume scan is used in the following sections as the time of radar observation. The origin of the Cartesian coordinates in figures related to Doppler radar observation, is set at the Shouxian observation site, with the $\mathrm{X}$-axis positive toward the east, and the $\mathrm{Y}$-axis positive toward the north.

In the present analysis, rainwater content $\left(\mathrm{M}: \mathrm{g} \mathrm{m}^{-3}\right)$ and rainfall intensity $\left(\mathrm{R}: \mathrm{mm} \mathrm{h}^{-1}\right.$ ) are converted from the radar reflectivity factor (Z: $\mathrm{mm}^{6} \mathrm{~m}^{-3}$ ) of the Shouxian radar using the following relationships (Jones 1956), respectively:

$$
\begin{aligned}
Z & =486 R^{1.37}, \\
M & =0.052 R^{0.97} .
\end{aligned}
$$

These relationships were used in the calculation of radar data for all heights. Some qualitative errors might be caused in the estimation of rainwater content for hydrometeors in a solid phase at the upper levels.

The data of upper-air sounding at the Fuyang and Nanjing Meteorological Observatories, which are $100 \mathrm{~km}$ away northwestward, and $200 \mathrm{~km}$ away east-southeastward from the Shouxian Doppler-radar site, respectively, were also used in the analysis. 


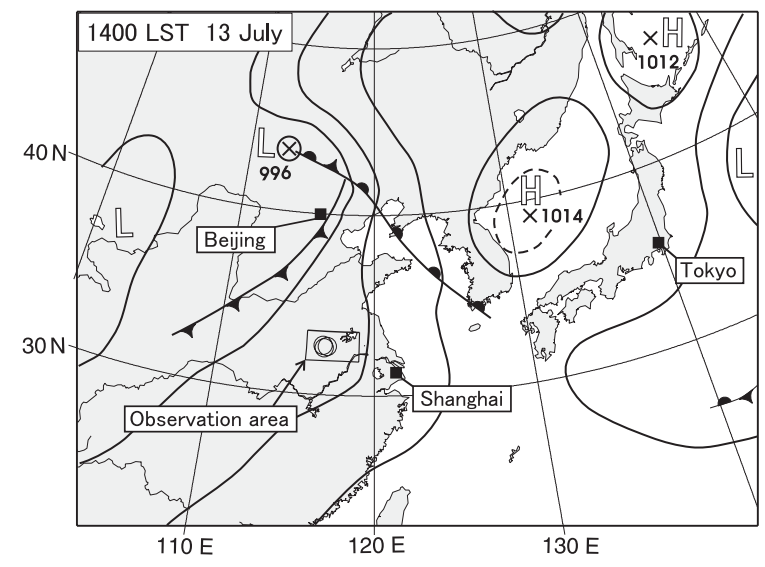

Fig. 2. Surface weather map at 1400 LST, 13 July 1998. The frame of Fig. 1 is shown by the rectangle in the figure.

\section{Brief description of the atmospheric situation}

Figure 2 shows the surface weather map at $1400 \mathrm{LST}(\mathrm{LST}=\mathrm{UTC}+8$ hours $), 13$ July 1998. A low-pressure center was located around $44^{\circ} \mathrm{N}$ and $113^{\circ} \mathrm{E}$. Its trailing cold and warm fronts extended southwestward and southeastward, respectively. Doppler radar observation sites are located about $1000 \mathrm{~km}$ southward from the low-pressure center. GMS infrared imagery shows that the observation area of the Doppler radars was not covered with a synoptic-scale cloud system around 1400 LST (not shown).

Figure 3 shows the vertical profiles of the temperature and dew-point temperature observed at 1400 LST, 13 July, at the Fuyang Meteorological Observatory. The air temperature reached $37^{\circ} \mathrm{C}$, and the water vapor mixing ratio was $21 \mathrm{~g} \mathrm{~kg}^{-1}$ at the surface. A layer drier than $40 \%$ was found around $3 \mathrm{~km}$ AGL. The freezing level was at about $5.8 \mathrm{~km}$. The lifting condensation level and the level of free convection were $1.5 \mathrm{~km}$ and $2.2 \mathrm{~km}$, respectively, as determined by a parcel having the averaged properties of the lowest $50 \mathrm{hPa}$ of the sounding. The equilibrium level of the adiabatically ascending air-parcel was about $14 \mathrm{~km}$ AGL. The convective available potential energy (CAPE) was $2300 \mathrm{~J} \mathrm{~kg}^{-1}$. The atmosphere observed at Fuyang was convectively unstable enough for cumulonimbus clouds to develop.

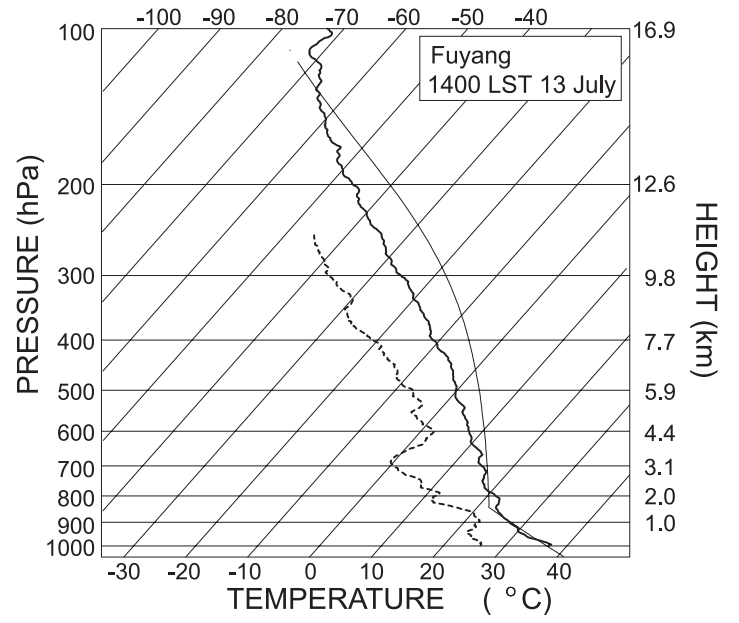

Fig. 3. Vertical profiles of air temperature (thick solid line) and dew-point temperature (dashed line) observed at Fuyang at 1400 LST, 13 July 1998. A thin solid line indicates the path of an adiabatic ascent of air having the averaged properties of the lowest $50 \mathrm{hPa}$ of the sounding.

As shown in the wind hodograph of Fig. 4, a southwesterly wind was predominant up to $14 \mathrm{~km}$ AGL, with a maximum speed of $15 \mathrm{~m} \mathrm{~s}^{-1}$ at $8 \mathrm{~km}$ AGL. The vertical wind shear between the surface and $5 \mathrm{~km}$ AGL was oriented toward the north-northeast, with a magnitude of $1.6 \mathrm{~m} \mathrm{~s}^{-1} \mathrm{~km}^{-1}$. The southwesterly wind was also dominant below $11 \mathrm{~km}$ at Nanjing, though it was weaker than that at Fuyang (not shown). Shouxian Doppler radar data at the elevation angle of $0.5^{\circ}$ showed that the weak southerly wind was predominant at the low levels during the observation period in the Doppler radar observation area. This is consistent with the sounding data at Fuyang and Nanjing. The ambient winds relative to the mean motion of cellular echoes in the present study, which will be defined later and are indicated by the open circle in Fig. 4, were northerly to westerly below $3 \mathrm{~km}$ AGL. The atmospheric situation around 1400 LST is characterized by weak vertical wind shear, the abundant water vapor at the low level, and a large CAPE.

\section{Convective echoes observed on $\mathbf{1 3}$ July 1998}

On 13 July, more than 15 convective echoes were observed in the observation area of the 


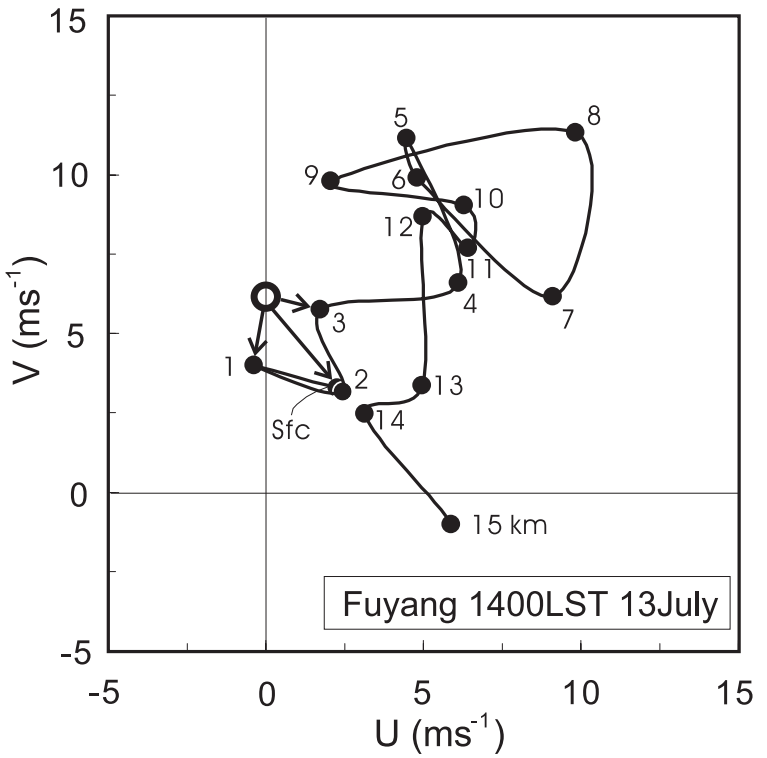

Fig. 4. Wind hodograph at Fuyang at 1400 LST, 13 July 1998. The open circle indicates the mean motion of cellular echoes within convective echo C. Arrows indicate cell-relative winds.

Doppler radars during the period from 1350 to 1900 LST. In this paper, the area of radar reflectivity $(10 \log Z)$ stronger than $10 \mathrm{dBZ}$ at $1 \mathrm{~km}$ AGL is referred to as a "convective echo," which almost corresponds to a cumulonimbus cloud. Although most convective echoes dis- appeared within 60 minutes after their appearance, five convective echoes were observed for longer than 60 minutes. Three of the five convective echoes were named convective echoes $A$, $\mathrm{B}$, and $\mathrm{C}$ and were located in close proximity. Convective echo $\mathrm{C}$, which is of interest, was observed for 217 minutes after its appearance, and it then exited the observation area before dissipating. Four other long-lasting convective echoes, including convective echoes A and B, appeared and disappeared within the Dopplerradar observation area. Their life spans ranged from 98 to 156 minutes. Convective echo $\mathrm{C}$ attained $490 \mathrm{~km}^{2}$ in maximum horizontal area (above $10 \mathrm{dBZ}$ at $1 \mathrm{~km}$ AGL), and was much larger than the other four convective echoes, which were smaller than $190 \mathrm{~km}^{2}$. It is noteworthy that only convective echo $\mathrm{C}$ exceeded $19 \mathrm{~km}$ AGL in echo-top height, and $50 \mathrm{dBZ}$ in reflectivity among the observed convective echoes on this day. In the following, the overall characteristics of convective echo $\mathrm{C}$ will be described in comparison with those of convective echoes A and B, which developed and persisted for 1 hour or more in close locations under the same atmospheric condition.

To show the overall evolution of convective echoes $\mathrm{A}, \mathrm{B}$, and $\mathrm{C}$, the horizontal distributions of the vertically integrated rainwater (VIR) are shown in Fig. 5. Convective echoes A, B, and C began to develop in the same group composed

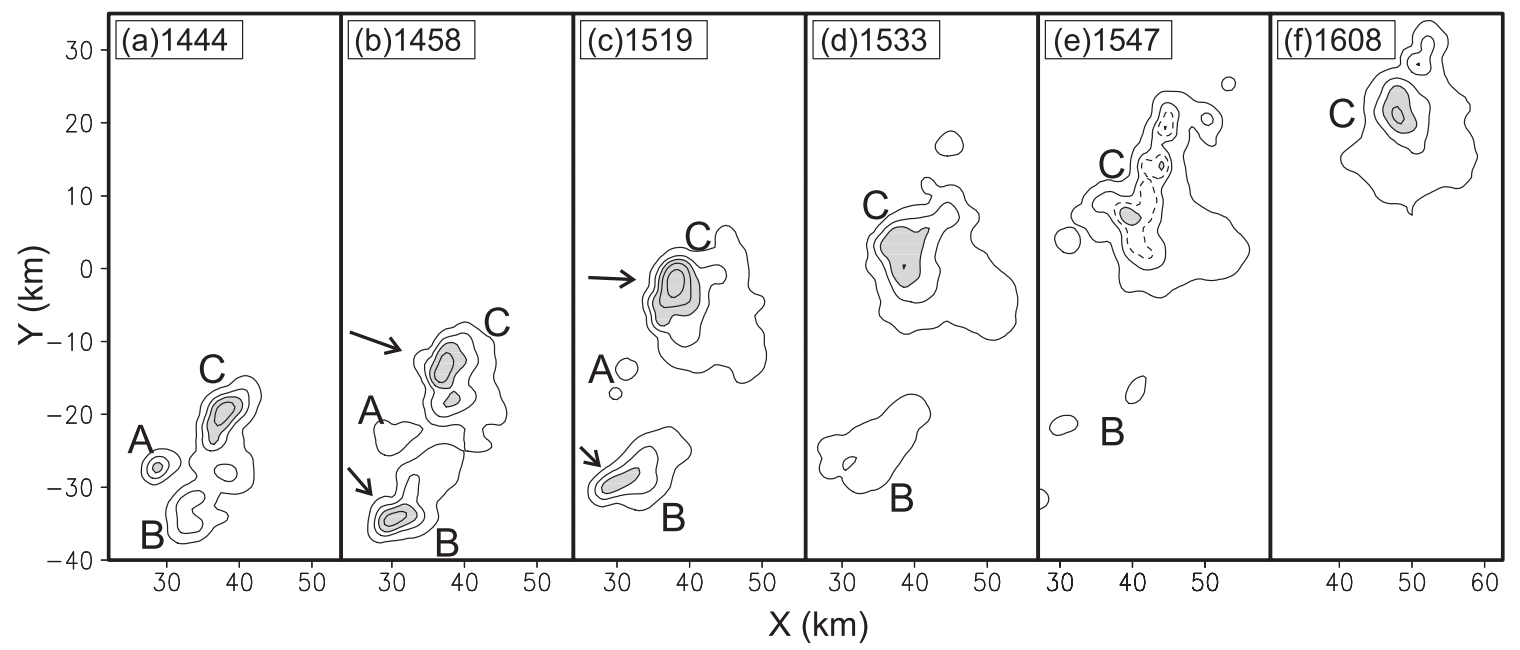

Fig. 5. Horizontal distribution of the amounts of vertically integrated rainwater in convective echoes $\mathrm{A}, \mathrm{B}$, and C. The contours indicate $0.1,1,2.5,5$, and $10 \mathrm{~kg} \mathrm{~m} \mathrm{~m}^{-2}$. Areas above $2.5 \mathrm{~kg} \mathrm{~m}^{-2}$ are shaded. The dashed lines in (e) represent contours of $1.75 \mathrm{~kg} \mathrm{~m}^{-2}$. Arrows in (b) and (c) are the viewing angles of the photographs in Fig. 6. 

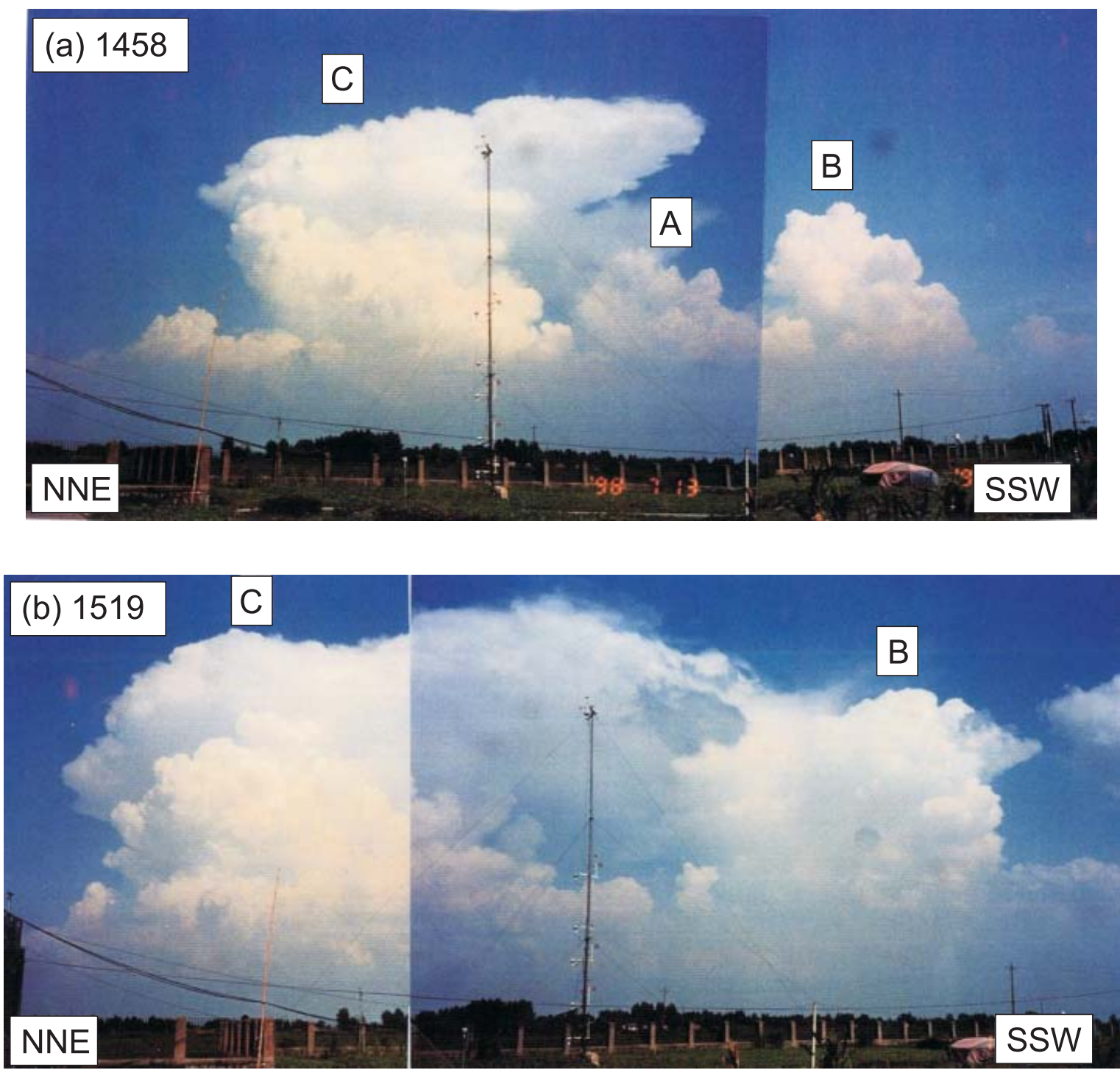

Fig. 6. Pictures of cumulonimbus clouds A, B, and C at (a) 1458 LST and (b) 1519 LST. The pictures were taken toward the east-southeast from the Shouxian Doppler-radar site.

of several small convective echoes at $1350 \mathrm{LST}$ (not shown). These three convective echoes became identifiable by 1444 LST (Fig. 5a). The mean motion of convective echo $\mathrm{C}$ from 1440 to 1615 LST is about $9.6 \mathrm{~m} \mathrm{~s}^{-1}$ toward $14^{\circ}$.

At 1444 LST, convective echo A in the western part of the echo group attained its greatest intensity in VIR, and decreased shortly afterwards. Convective echo $\mathrm{C}$ had already been a dominant feature and partially merged with convective echo B to the south (Fig. 5a). They aligned almost in the direction of the ambient vertical wind shear at the low to middle levels and separated farther and farther from each other in the next 60 minutes. Convective echo $\mathrm{B}$ exhibited rapid intensification around 1458 LST, and split from convective echo C. It gradually weakened after 1519 LST, and dissipated by 1608 LST (Figs. 5a-5f).

For about 30 minutes after 1444 LST, convective echo $\mathrm{C}$ barely changed its maximum VIR. At 1519 LST, the VIR of convective echo C abruptly increased and reached $13 \mathrm{~kg} \mathrm{~m}^{-2}$, which is the greatest value observed in the period from 1440 to 1615 LST (Fig. 5c). At this time, the total rainwater amount (TRW), 
which is a three-dimensionally integrated water amount in convective echo $\mathrm{C}$, was also maximum and exceeded $4.0 \times 10^{8} \mathrm{~kg}$. It was more than three times as much as the maxima in TRW of convective echoes $\mathrm{A}$ and $\mathrm{B}$, which were $0.2 \times 10^{8} \mathrm{~kg}$ at $1444 \mathrm{LST}$ and $1.2 \times 10^{8} \mathrm{~kg}$ at 1512 LST, respectively. After 1519 LST, the VIR of convective echo $\mathrm{C}$ continued to decrease, while the number of local maxima of VIR increased as clearly seen at 1547 LST (Fig. 5e). Around 1608 LST, the maximum VIR in convective echo $\mathrm{C}$ exceeded $5 \mathrm{~kg} \mathrm{~m}^{-2}$ again (Fig. 5f).

Figure 6 shows photographs of cumulonimbus clouds A, B, and C at 1458 and 1519 LST, which correspond to convective echoes $\mathrm{A}, \mathrm{B}$, and $\mathrm{C}$, respectively. These two pictures were taken toward the east-southeast from the Shouxian Doppler-radar site. The viewing angles of these photographs are indicated in Figs. $5 \mathrm{~b}$ and $5 \mathrm{c}$. The clouds moved from the right to the left (north-northeastward) of the figures. At 1458 LST, three cumulonimbus clouds were identified in the photograph (Fig. 6a). Cumulonimbus clouds B and C, especially cumulonimbus cloud C, grew dramatically at 1519 LST, while cumulonimbus cloud A almost vanished (Fig. 6b). Though convective echo $\mathrm{C}$ was observed until 1732 LST by Doppler radars, the following description of the radar-echo features is primarily based on the observation during the period from 1440 to 1615 LST.

The difference in evolution between convective echo $\mathrm{C}$ and the other convective echoes is obviously seen in the time variations of echotop height (defined by $10 \mathrm{dBZ}$ ) shown in Fig. 7. Convective echoes A and B had maximum echo tops of 8 and $14.5 \mathrm{~km}$, respectively. These highest echo tops were temporary and then gradually decreased. The echo top of convective echo $\mathrm{C}$, on the contrary, kept the height of $14 \mathrm{~km}$ or more for 1.5 hours with marked intermittent fluctuation, and its maximum height was $19 \mathrm{~km}$. It is also noted that the echo top of $35 \mathrm{dBZ}$ showed remarkable development to reach $15 \mathrm{~km}$ AGL around 1519 and 1608 LST.

The overall evolution of cellular echoes within convective echoes $\mathrm{A}, \mathrm{B}$, and $\mathrm{C}$ is presented in the projection of maximum radar-echo intensity onto a north-south vertical plane, which is nearly parallel to the low- to mid-level vertical wind shear observed at Fuyang (Fig. 8).

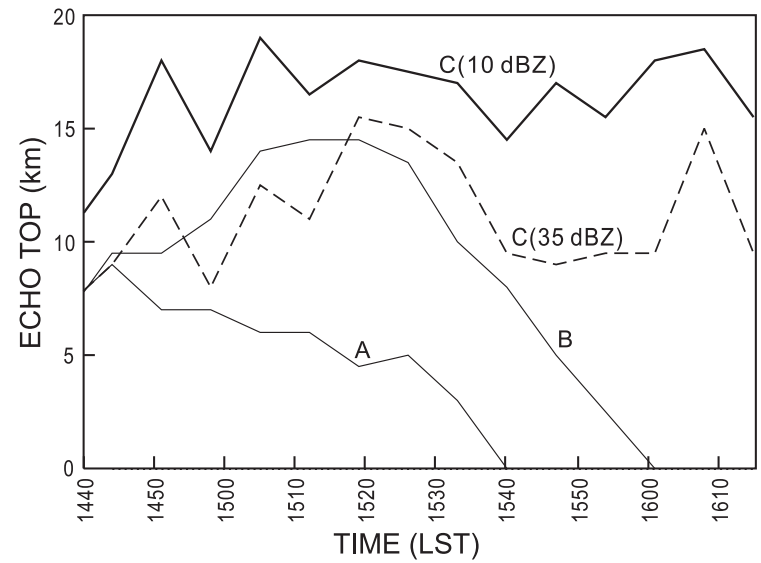

Fig. 7. Time variations of maximum echo-top heights of convective echoes $\mathrm{A}, \mathrm{B}$, and $\mathrm{C}$ defined by $10 \mathrm{dBZ}$ (solid lines) and $35 \mathrm{dBZ}$ of convective echo $\mathrm{C}$ (dashed line).

In this paper, a "cellular echo," which normally corresponds to a convective cell, is defined and traced by a region of radar echo above $20 \mathrm{dBZ}$ with a local maximum of reflectivity. Cellular echoes within these three convective echoes tended to align in the direction of vertical wind shear, that is, nearly parallel to the vertical plane in Fig. 8. Convective echo A consisted of one or two cellular echoes at each time. In convective echo A, a new cellular echo formed on its front (north) side, as seen at 1505 LST (Fig. 8d). In convective echo B, which consisted of two or three cellular echoes, new cellular echoes appeared on its rear (south) side in the vertical plane (Figs. 8a, 8d, and 8g).

The mean motion of cellular echoes in convective echo $C$, is about $7.0 \mathrm{~m} \mathrm{~s}^{-1}$ toward $0^{\circ}$. This mean motion is shown by the open circle in Fig. 4. The vertical planes in Fig. 8 are nearly normal to the mean motion of cellular echoes. New cellular echoes tended to form on the downshear side (the right side of the figure) of previous cellular echoes through the period in Fig. 8. Cellular echoes in convective echo $\mathrm{C}$ were identified and labeled in Fig. 8, between 1444 and 1526 LST (C1 through C4). Convective echo $\mathrm{C}$ consisted of about two or three cellular echoes at each time before 1526 LST. A remarkable radar-echo feature was found at 1519 LST, when two cellular echoes (C2 and C4) merged (Fig. 8f). A single large radar-echo 

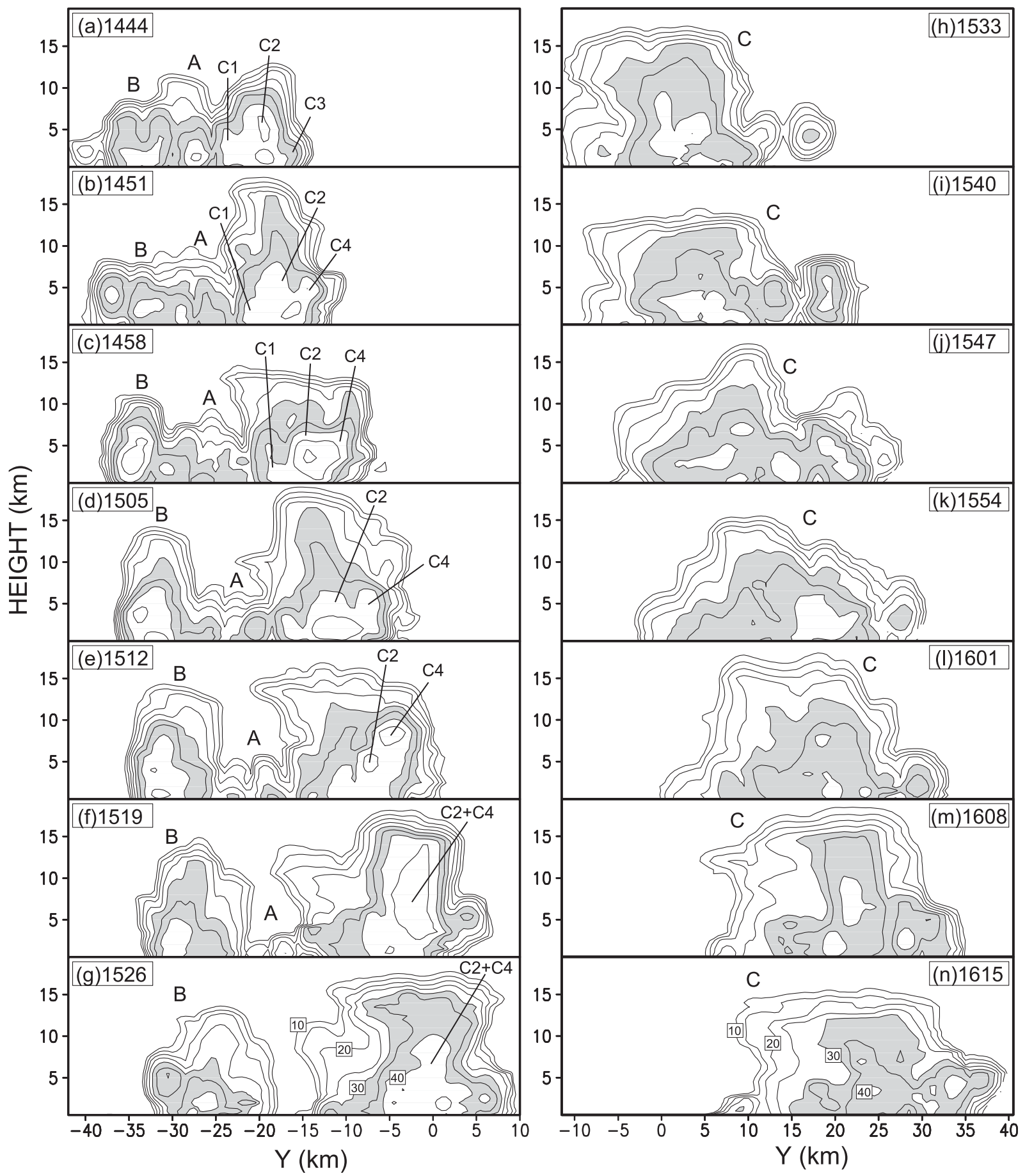

Fig. 8. Vertical distribution of maximum radar-echo intensity of convective echoes A, B, and C projected onto a north-south vertical section. Only convective echo C is shown after 1533 LST. The contours of radar-echo intensity are drawn every $5 \mathrm{dBZ}$ from $10 \mathrm{dBZ}$. Areas from 30 to $40 \mathrm{dBZ}$ are shaded. 
stronger than $40 \mathrm{dBZ}$ was observed. It was nearly upright, and had a horizontal diameter of about $7 \mathrm{~km}$ up to $15 \mathrm{~km}$ AGL in the vertical plane.

Although the cellular echoes are not labeled after 1533 LST in Figs. 8h-8n, the number of cellular echoes increased until 1547 LST (Fig. 8j), and decreased around 1608 LST (Fig. 8m). It is noteworthy that an intense echo stronger than $35 \mathrm{dBZ}$ suddenly developed up to $15 \mathrm{~km}$ AGL at 1608 LST (Fig. 8m). The radar-echo structure at 1608 LST was qualitatively similar to that at 1519 LST, while radar-echo intensities were weaker than those at 1519 LST.

\section{Three-dimensional structure of convective echo $\mathbf{C}$}

\subsection{Stages of evolution}

The evolution of convective echo $\mathrm{C}$ from 1440 to 1615 LST is illustrated in Fig. 9 in terms of the time variation of horizontal echo areas above $35 \mathrm{dBZ}$ at 3, 6, 9, and $12 \mathrm{~km}$ AGL. During the 1.5-hour period, the echo area at $3 \mathrm{~km}$ AGL changed significantly, while that at $6 \mathrm{~km}$ AGL changed very little. Note that echo areas at 9 and $12 \mathrm{~km}$ AGL attained remarkably large sizes that were almost equal to that at $6 \mathrm{~km}$ AGL around 1520 and 1610 LST.

On the basis of Fig. 9, the evolution of convective echo $\mathrm{C}$ during this period was divided

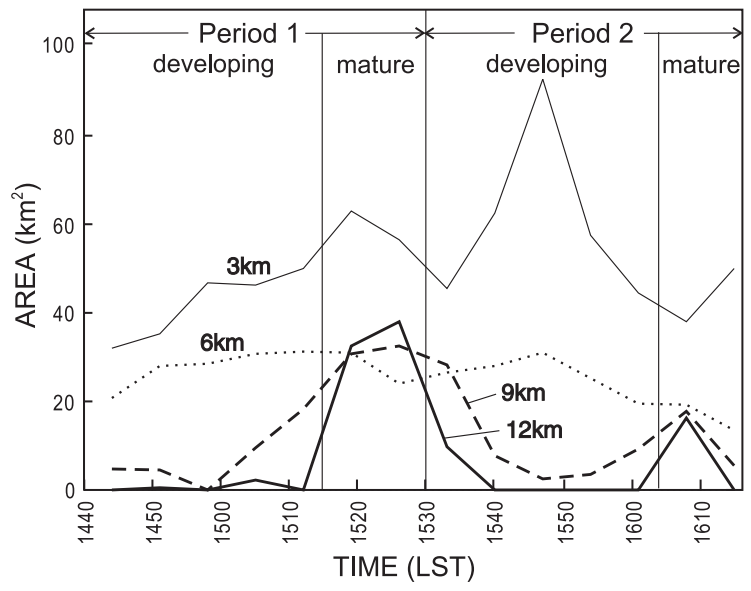

Fig. 9. Time variations of the horizontal area of convective echo $\mathrm{C}$ above $35 \mathrm{dBZ}$ at $3 \mathrm{~km}$ (thin solid line), $6 \mathrm{~km}$ (short dashed line), $9 \mathrm{~km}$ (long dashed line), and $12 \mathrm{~km}$ AGL (thick solid line). into Period 1 (from 1440 to 1530 LST) and Period 2 (from 1530 to 1615 LST). Each period includes two stages: the developing stage, in which the echo area above $35 \mathrm{dBZ}$ decreased with the height (from 1440 to 1515 LST in Period 1, from 1530 to 1605 LST in Period 2), and the mature stage, in which the echo areas were almost the same at 6,9 , and $12 \mathrm{~km} \mathrm{AGL} \mathrm{(from}$ 1515 to 1530 LST in Period 1, from 1605 to 1615 LST in Period 2). In the following description, the structure of convective echo $\mathrm{C}$ during Period 1 will be presented in detail, because convective echo $\mathrm{C}$ exhibited greater intensities during Period 1 than during Period 2 in terms of areas of intense radar echo at upper levels (Fig. 9). In addition, the threedimensional airflows during Period 1 were deduced from dual-Doppler measurements.

\subsection{Developing stage: The period of 1440 $L S T-1515$ LST}

The evolution of cellular echoes within convective echo $\mathrm{C}$ during the developing stage is illustrated in Figs. 10a-10e, using a sequence of horizontal echo distributions at $5 \mathrm{~km}$ AGL. At $1444 \mathrm{LST}$, convective echo $\mathrm{C}$ was composed of three cellular echoes, C1, C2, and C3 (Fig. 10a). At 1451 LST, cellular echo C4 appeared in the front (downshear) part of convective echo $\mathrm{C}$ (Fig. 10b). Cellular echoes C2 and C4 dominated the convective echo during the next 35 minutes. Cellular echo C2 developed vigorously and showed large fluctuation in its vertical extent during the developing stage, as seen in Figs. 8a-8e. Explosive development of cellular echo C4 occurred at 1512 LST, with the strong echo region above $45 \mathrm{dBZ}$ around $8.5 \mathrm{~km}$ AGL (Fig. 8e).

Four volume scans at $1444,1451,1458$, and 1505 LST were performed to deduce the threedimensional wind field using dual-Doppler radar measurements during the developing stage. The horizontal distributions of vertical air velocity at 2.5 and $5 \mathrm{~km}$ AGL are depicted in Figs. $10 \mathrm{f}-10 \mathrm{~m}$, and the wind vector at $2.5 \mathrm{~km}$ AGL is shown in Figs. 10n-10q. In this paper, all velocities are relative to the averaged movement of cellular echoes within convective echo $\mathrm{C}\left(7.0 \mathrm{~m} \mathrm{~s}^{-1}\right.$ toward $0^{\circ}$ in azimuth). Cellular echoes, and their associated updrafts and downdrafts, will be indicated by the same numbers in their name. 


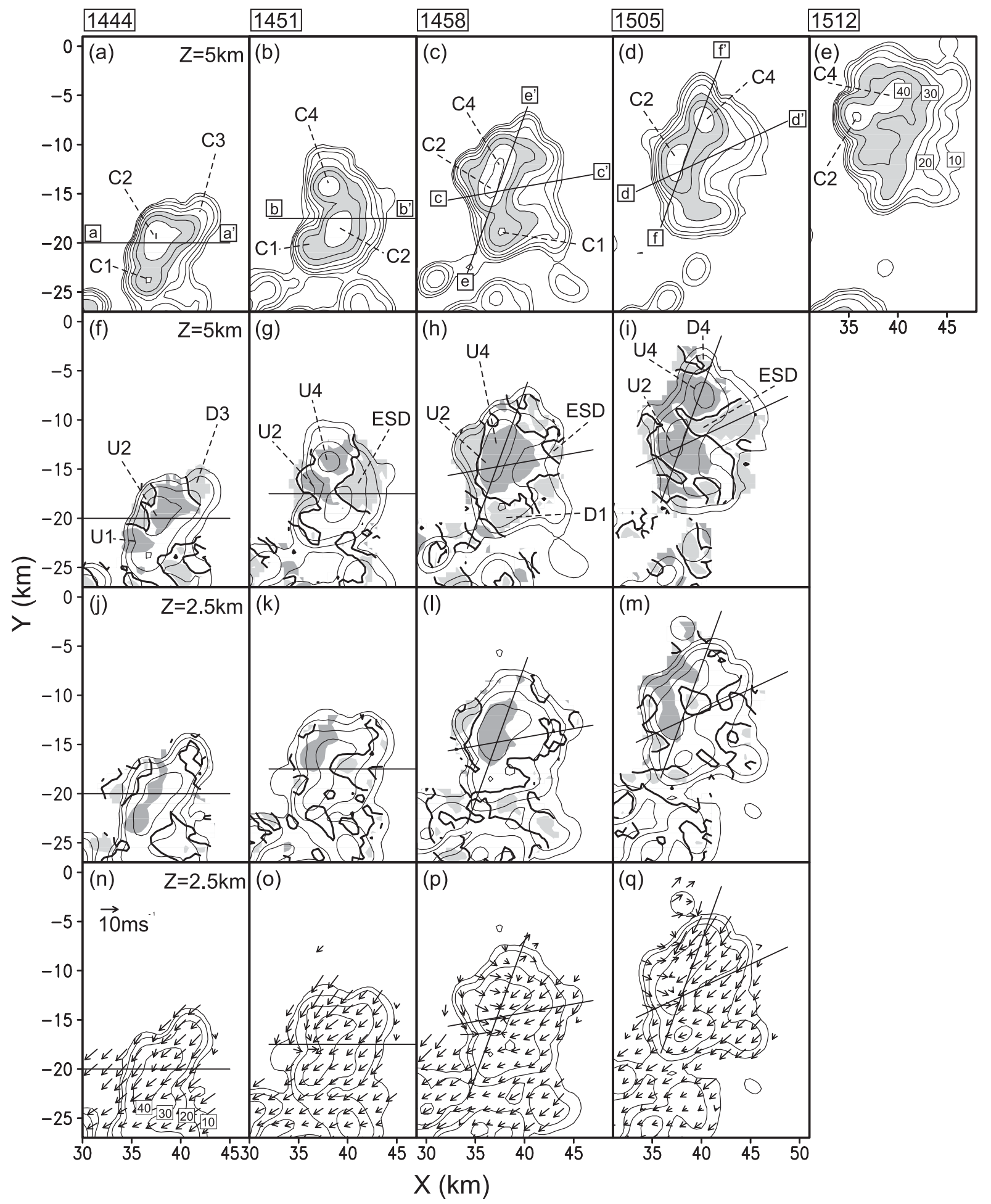

Fig. 10. Horizontal sections of echo and cell-relative wind fields during the developing stage. The top row (a)-(e) shows the radar-echo intensity at $5 \mathrm{~km}$ AGL. The contours and shades of radarecho intensity are the same as in Fig. 8. The second (f)-(i) and third (j)-(m) rows show vertical air velocity (shadings) at 5 and $2.5 \mathrm{~km}$ AGL, respectively. Regions of updraft larger than $5 \mathrm{~m} \mathrm{~s}^{-1}$ and those of downdraft less than $-2 \mathrm{~m} \mathrm{~s}^{-1}$ are darkly and lightly shaded, respectively. The thick solid contours are at $0 \mathrm{~m} \mathrm{~s}^{-1}$. The bottom row (n)-(q) shows horizontal wind vectors at $2.5 \mathrm{~km}$ AGL. In the three lower rows, contours of radar-echo intensity of 10, 20, 30, and $40 \mathrm{dBZ}$ from the outside are also shown. The locations of the vertical sections in Fig. 11 are depicted in each figure. 
During the developing stage, a northeasterly wind was predominant at the low to middle levels within convective echo $\mathrm{C}$ (Figs. 10n-10q). At 1444 LST, cellular echoes C1 and C2 had updrafts U1 and U2, respectively (Figs. 10f and 10j). Cellular echo C3 was already occupied by downdraft D3 (Figs. 10f and 10j). At 1451 LST, updraft U2 continued in the western part of convective echo $\mathrm{C}$, and its updraft core slightly shifted from the echo core of C2 (Figs. 10g and 10k). The new cellular echo $\mathrm{C} 4$ had an intense updraft U4. It is noted that a downdraft appeared at 2.5 and $5 \mathrm{~km}$ AGL on the eastern side of the convective echo, which is the vertical component of the descending northeasterly airflow. The downdraft will be referred to as the eastern-side downdraft (ESD). A low-level westerly wind began to appear around U2 at $2.5 \mathrm{~km}$ AGL, and collided with the northeasterly wind (Fig. 10o). At 1458 LST, updrafts U2 and U4 became larger at 2.5 and $5 \mathrm{~km}$ AGL (Figs. $10 \mathrm{l}$ and $10 \mathrm{~h}$ ). It is noteworthy that a notch of a radar echo appeared on the eastern side of the convective echo around $5 \mathrm{~km}$ AGL (Fig. 10c) in the northeasterly wind region, while the ESD was not so remarkable at this time. This echo notch will be referred to as the eastern-side notch (ESN). The westerly inflow strengthened and expanded in the western part of convective echo $\mathrm{C}$ at low levels (Fig. 10p). At 1505 LST, the area of the ESD expanded around the ESN where the northeasterly wind continued to blow at low and middle levels (Figs. 10i, 10m, and 10q). Updrafts and echo cores of $\mathrm{C} 2$ and $\mathrm{C} 4$ were clearly identified at 2.5 and $5 \mathrm{~km}$ AGL (Figs. 10i and $10 \mathrm{~m}$ ). The lowlevel westerly inflow further strengthened, and expanded in the western part of convective echo C, at $2.5 \mathrm{~km}$ AGL (Fig. 10q). A downdraft region (D4) appeared on the front (northern) side of convective echo $\mathrm{C}$ around $5 \mathrm{~km}$ AGL (Fig. 10i), although it had not reached the ground yet.

Figure 11 shows the vertical sections along the lines in Fig. 10. The vertical sections a-a' to $d-d^{\prime}$ in Fig. 11 were selected to cut the cellular echo C2 and updraft U2 in the direction nearly normal to the low-level vertical wind shear. At 1444 LST, the echo core of cellular echo C2 was almost upright in the a-a' section. Updraft U2 was also upright around the echo core, while it tilted to the east at upper levels. The $b-b^{\prime}$ sec- tion at 1451 LST shows that both axes of C2 and U2 tilted slightly to the east at the low and middle levels. The vertical section $b-b^{\prime}$ clearly indicates that the low-level westerly inflow coming into updraft U2 was forced upward by the descending northeasterly airflow. At 1458 LST, the intense echo region of C2 was located in the western part of the convective echo in the vertical section $\mathrm{c}-\mathrm{c}^{\prime}$. The ESN was obviously seen around $5 \mathrm{~km}$ AGL. The lowlevel westerly inflow collided with the low-level northeasterly airflow in the lower part of updraft U2. The axis of U2 tilted to the east. The vertical section $\mathrm{d}^{-\mathrm{d}^{\prime}}$ at 1505 LST shows that the axes of both C2 and U2 tilted to the east. The ESN had extended downward, and it coexisted with the descending northeasterly airflow, which continued to force the westerly inflow into U2. The noteworthy points in the vertical sections $a-a^{\prime}$ to $d-d^{\prime}$ in the developing stage are that the low-level westerly inflow coming into updraft U2 was persistently forced upward by the descending northeasterly airflow after 1451 LST, and that the axes of updraft U2 and cellular echo C2 gradually tilted to the east, that is, in the direction nearly normal to the ambient low-level vertical wind shear.

The vertical sections $e-e^{\prime}$ and $f-f^{\prime}$ in Fig. 11 were selected to cut the cellular echoes $\mathrm{C} 2$ and $\mathrm{C} 4$ in the direction nearly parallel to the ambient low-level vertical wind shear. In the vertical section e-e' $e^{\prime}$ at $1458 \mathrm{LST}$, the core of updraft U2 was upright, but sloped to the east (the c-c' section in Fig. 11). The vertical section $\mathrm{f}^{\prime} \mathrm{f}^{\prime}$ at 1505 LST indicates that both updrafts U2 and U4 inclined to the downshear side (to the right side of the figure).

\subsection{Mature stage: The period of 1515 LST- $1530 \mathrm{LST}$}

Horizontal reflectivity distributions at selected levels at 1519 LST are shown in Fig. 12. Cellular echoes C2 and C4 had grown in size and intensity, and were encompassed by the 40-dBZ contour at all levels. Although the two reflectivity cores were identified at $2.5 \mathrm{~km}$ AGL (Fig. 12a), only a single reflectivity core was observed at the upper levels (Figs. 12b-12d). This radar-echo region stronger than $40 \mathrm{dBZ}$ is hereafter referred to as the strong echo region (SER). The SER showed almost the same area up to $15 \mathrm{~km}$ AGL. It elongated along the direc- 

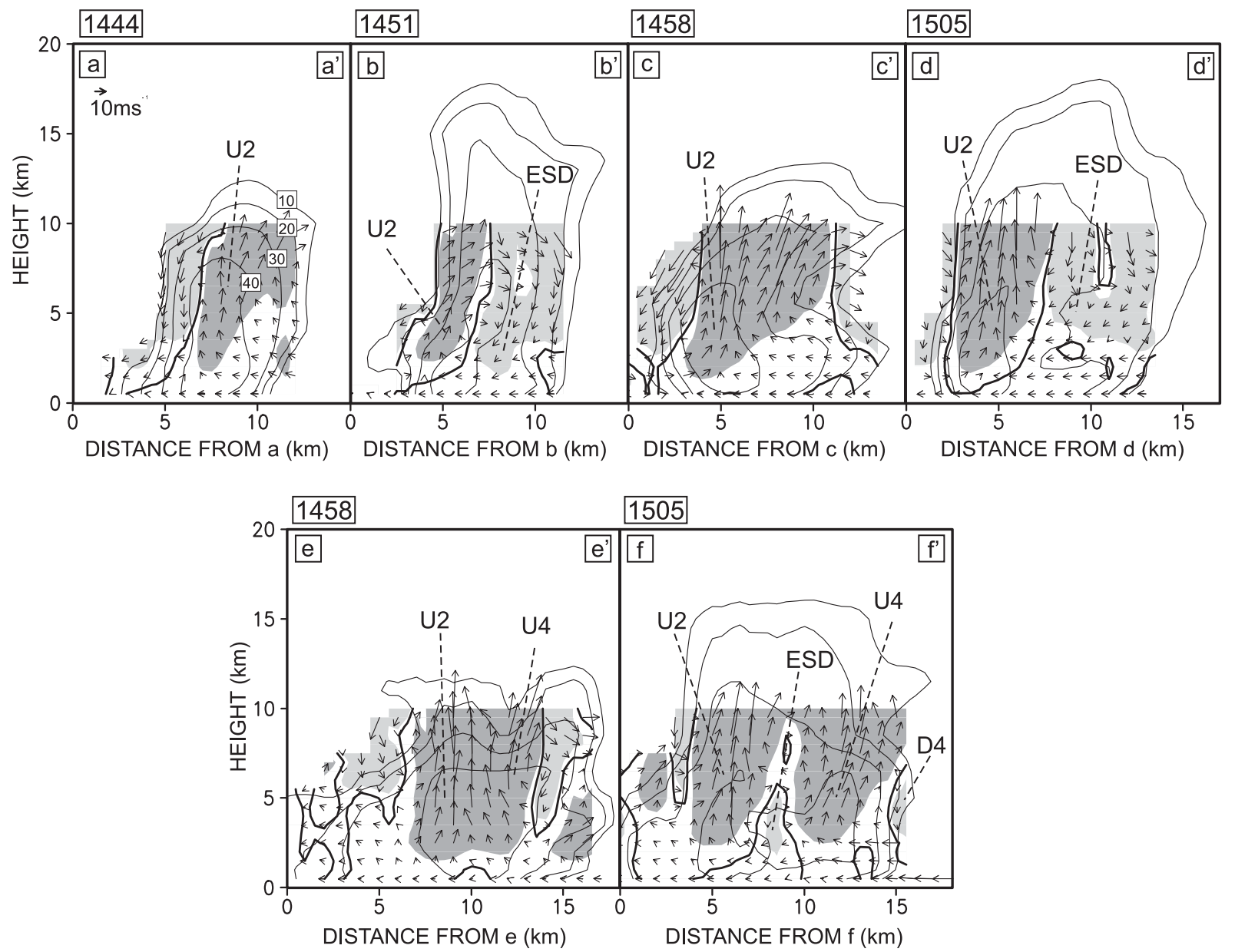

Fig. 11. Vertical sections of echo and cell-relative wind fields during the developing stage. Sections $\mathrm{a}-\mathrm{a}^{\prime}$ to $\mathrm{d}-\mathrm{d}^{\prime}$ are nearly normal to the vertical wind shear of the environment. Sections e-e' and $\mathrm{f}^{\prime} \mathrm{f}^{\prime}$ are nearly parallel to the vertical wind shear. The locations of the sections are shown in Fig. 10. The shaded regions and thick solid contours of vertical velocities are the same as in Fig. 10. The contours of radar-echo intensity indicate 10, 20, 30, and $40 \mathrm{dBZ}$ from the outside.

tions from northeast to southwest at $2.5 \mathrm{~km}$ AGL (Fig. 12a), from north to south at 5 and $8.5 \mathrm{~km}$ (Figs. $12 \mathrm{~b}$ and $12 \mathrm{c}$ ), and from northnorthwest to south-southeast at $12 \mathrm{~km}$ AGL (Fig. 12d). The ESN was still observed to the east of the SER at 2.5 and $5 \mathrm{~km}$ AGL (Figs. 12a and $12 \mathrm{~b}$ ). It was more obvious at this time than that in the developing stage.

Figure 13 shows the vertical sections along the lines in Fig. 12. Sections g-g' and h-h' indicate that the SER was almost upright in the north-south cross section. In contrast, the SER sloped to the east (right) in the rear portion (the section $\mathrm{j}-\mathrm{j}^{\prime}$ in Fig. 13), but was upright in the front portion (the section $\mathrm{i}-\mathrm{i}^{\prime}$ in Fig. 13). The ESN is also shown clearly in the vertical section $\mathrm{j}-\mathrm{j}^{\prime}$ in Fig. 13.

The horizontal distributions of airflow at 1519 LST are shown in Fig. 14. The cellrelative northeasterly wind was predominant inside convective echo $\mathrm{C}$ at the low to middle levels (Figs. 14a-14c). As shown in Figs. 14d14f, two significant updrafts, U2 and U4, existed in the southwestern (upshear) and the northern (downshear) portions of the convective echo, respectively. At 1 and $2.5 \mathrm{~km}$ AGL, U2 coexisted with the echo core of $\mathrm{C} 2$, and $\mathrm{U} 4$ was present in the northern part of cellular echo C4 

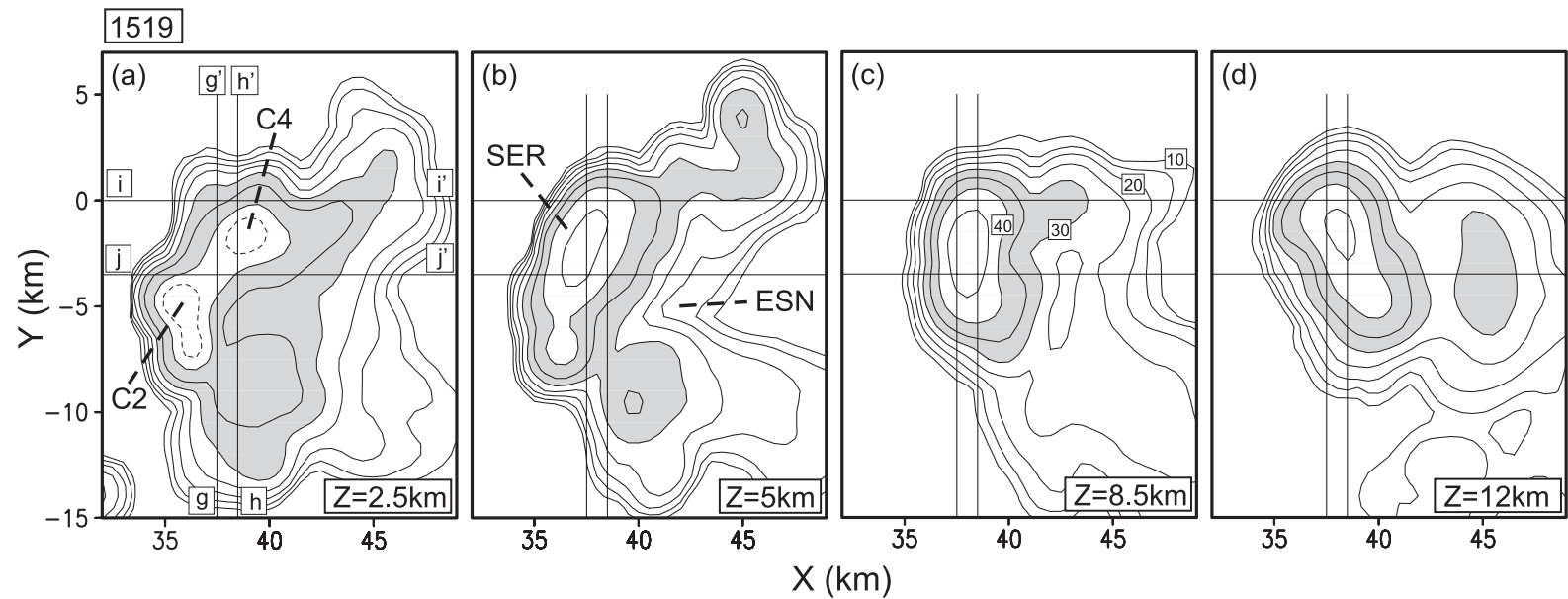

Fig. 12. Horizontal sections of the echo field at 2.5, 5, 8.5, and $12 \mathrm{~km}$ AGL at 1519 LST. The contours and shades of radar-echo intensity are the same as in Fig. 8. The dashed lines in (a) represent the contours of $42.5 \mathrm{dBZ}$.

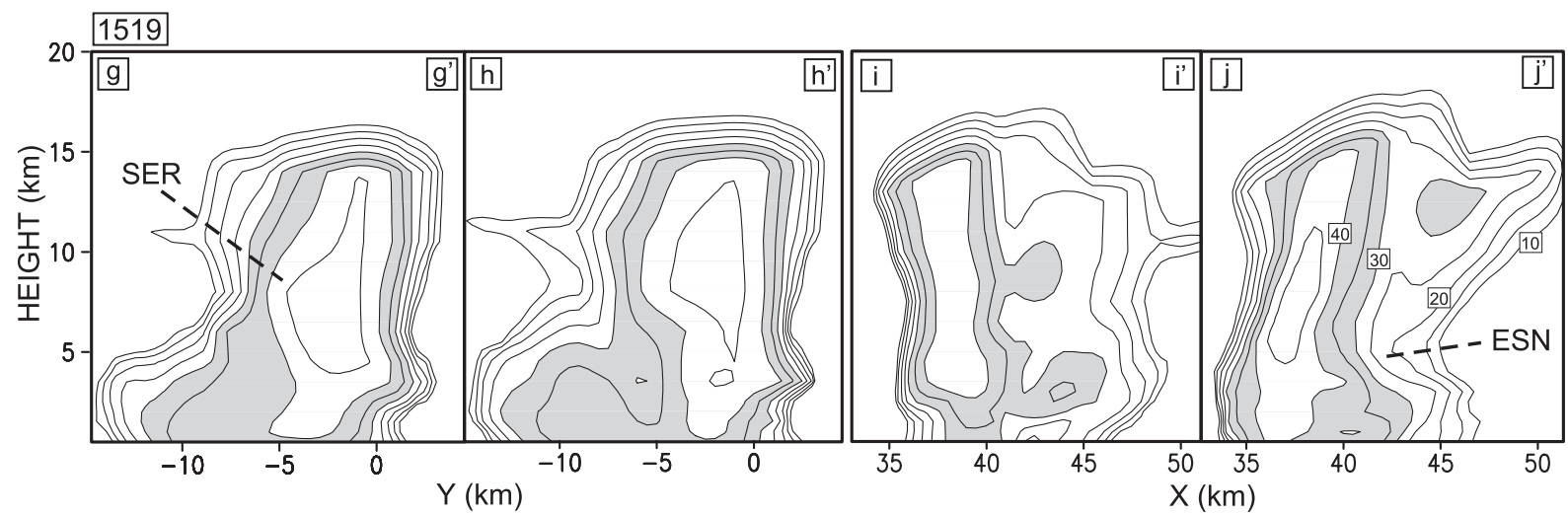

Fig. 13. Vertical cross sections of the echo field at 1519 LST. The contours and shades of radar-echo intensity are the same as in Fig. 8. The locations of vertical cross sections are indicated in Fig. 12.

(Figs. 14d and 14e). The westerly inflow collided with the northeasterly wind around the foot of updraft U2 (Figs. 14a and 14b), and a large convergence existed there (Fig. 14d). The northerly inflow was seen around the foot of updraft $\mathrm{U} 4$, and the convergence region was located immediately to the north of the echo core of C4 at $1 \mathrm{~km}$ AGL (Figs. 14a and 14d). The ESD was still observed, and coexisted with the ESN at the low to middle levels in the predominant northeasterly wind (Figs. 14d-14f). At $1 \mathrm{~km}$ AGL, the ESD was expanded below the intense echo region of $\mathrm{C} 4$ (Fig. 14d).

Figure 15 shows the vertical cross sections of wind and reflectivity fields along the lines shown in Fig. 14. The vertical section k-k' was selected to cut updraft U2 and the ESD. The difference between the direction of section $\mathrm{k}-\mathrm{k}^{\prime}$ and that of the low-level vertical wind shear is relatively large, while the left and right sides of the section roughly correspond to the upshear and downshear sides, respectively. Both the axes of updraft U2 and the SER tilted to the right (east-northeast) side of section $\mathrm{k}-\mathrm{k}^{\prime}$. In the lower part of updraft U2, the descending northeasterly airflow collided with the low-level inflow coming into U2 from the southwestern (upshear) side of the convective echo C. In the vertical section $1-\mathrm{l}^{\prime}$, nearly parallel to the lowlevel vertical wind shear, updraft U4 appar- 
Vol. 83 , No. 3

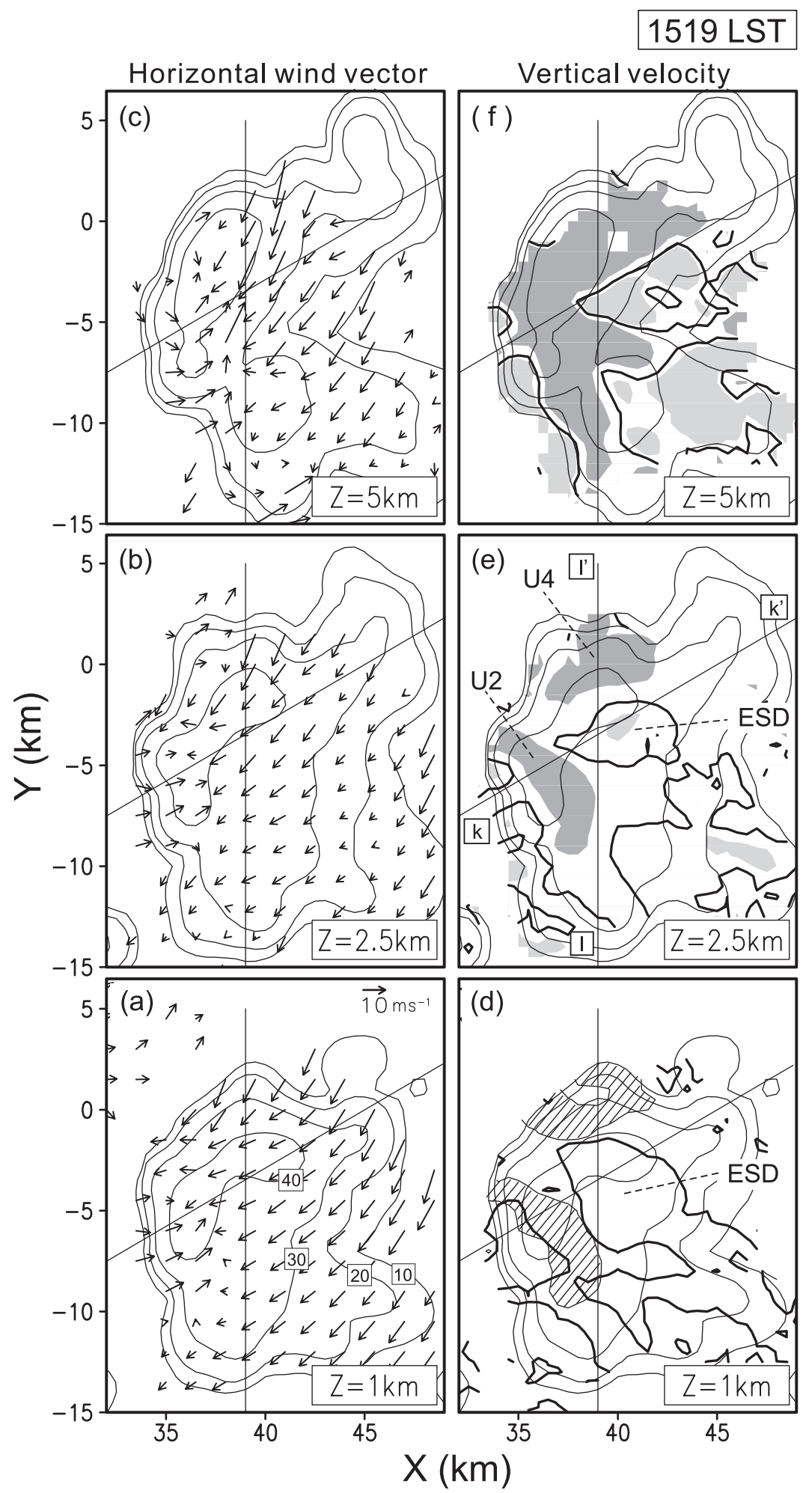

Fig. 14. Horizontal sections of cell-relative wind field at 1, 2.5, and $5 \mathrm{~km}$ AGL at 1519 LST. The left panels are horizontal wind vectors. The right panels are the vertical air velocity. The shaded regions and thick solid contours of vertical velocities are the same as in Fig. 10. Areas of horizontal convergence greater than $2.5 \times 10^{-3} \mathrm{~s}^{-1}$ at $1 \mathrm{~km}$ AGL are illustrated by hatched regions in (d). The contours of radar-echo intensity of $10,20,30$, and $40 \mathrm{dBZ}$ are also shown in each panel for reference. 


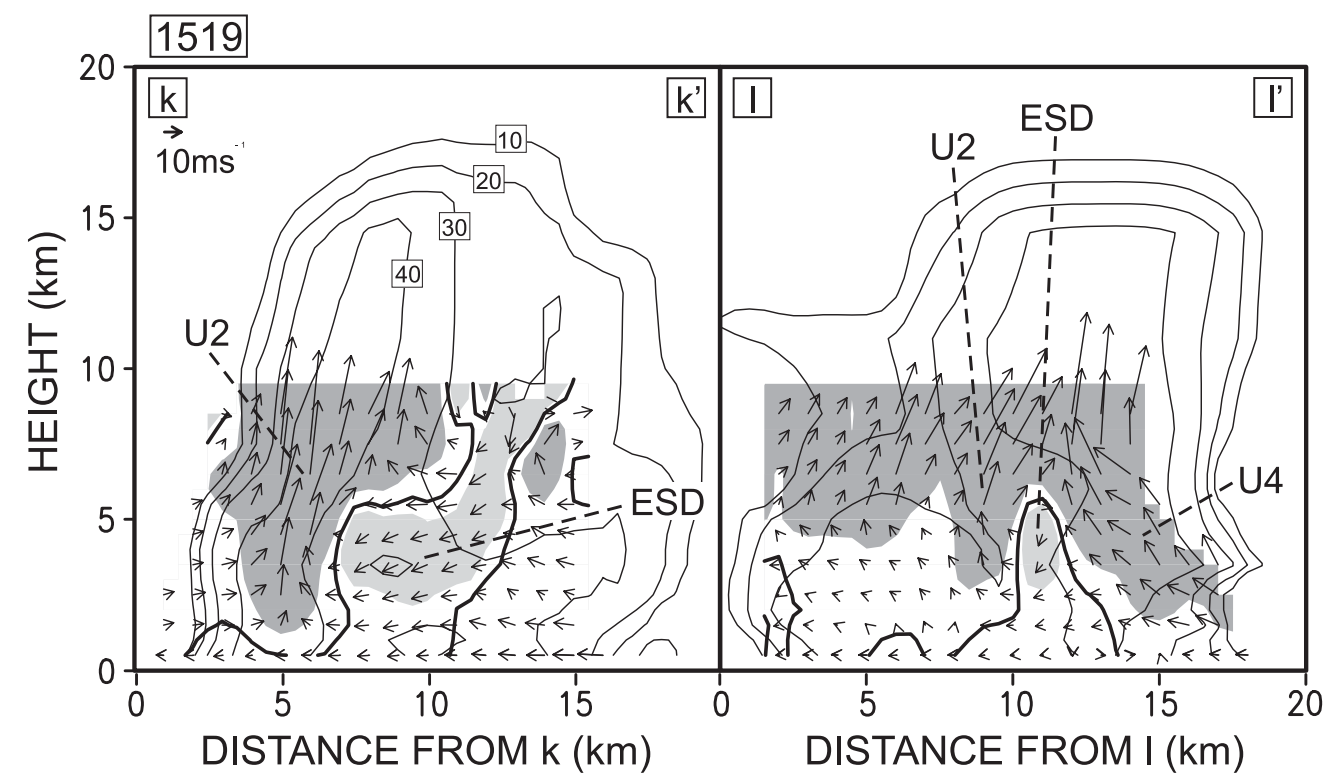

Fig. 15. Vertical sections of cell-relative wind field at 1519 LST. The locations of the sections are shown in Fig. 14. The shaded regions and thick solid contours of vertical velocities are the same as in Fig. 10. The contours of radar-echo intensity of 10, 20,30, and $40 \mathrm{dBZ}$ are also shown in each panel.

ently tilted to the southern (upshear) side, although it was tilted to the downshear side in the developing stage, as seen in section $\mathrm{f}-\mathrm{f}^{\prime}$ of Fig. 11. The ESD, which was located to the southern (upshear) side of U4, diverged northward near the surface and collided with the low-level northerly inflow coming into updraft U4. Only the upper part of U2, which shows the downshear tilting (to the right side of the figure), is observed in section $1-l^{\prime}$.

Selected horizontal and vertical distributions of reflectivity and wind fields at 1526 LST are presented in Fig. 16. The SER was located in the western portion of convective echo $\mathrm{C}$ (Fig. 16a), and still exceeded $10 \mathrm{~km}$ AGL (Fig. 8g). The ESN, and the ESD, were still found in the low- and mid-level northeasterly wind region in the eastern portion of convective echo C. The low-level westerly airflow coming into updraft U2 was continuously forced upward by the northeasterly airflow at low levels (Fig. 16a and section $\mathrm{m}-\mathrm{m}^{\prime}$ in Fig. 16b). Updraft U4 with upshear tilting was still substantial in the downshear part of the SER (Fig. 16a and section n-n' in Fig. 16b). The airflow structure in the mature stage was characterized by two significant updrafts, U2 and U4, which tilted to the downshear and upshear sides, respectively. They were not a temporary but, rather, a firmly established structure. The intensification of downdrafts around the SER (Fig. 16a) at 1526 LST indicates that the convective cells were close to the end of the mature stage.

\subsection{Schematic structure of the cumulonimbus cloud in the mature stage}

A schematic diagram of the radar-echo structure of the cumulonimbus cloud and significant air motions observed in the low and middle levels in the mature stage is illustrated in Fig. 17. As seen in the central illustration, updraft U2 in the southwestern (upshear) part of the cloud tilted to the northeastern (downshear) side at the low and middle levels. Updraft U4 in the northern (downshear) part of the cloud tilted to the southern (upshear) side. At the low levels, updraft U2 coexisted with the echo core of $\mathrm{C} 2$, and updraft $\mathrm{U} 4$ was present in the northern part of cellular echo C4. The ESD came from the northeasterly wind at low to middle levels and coexisted with the ESN.

The side wall in Fig. 17 shows the projection of maximum radar-echo intensity and significant air motions (U2, U4, and the ESD) 

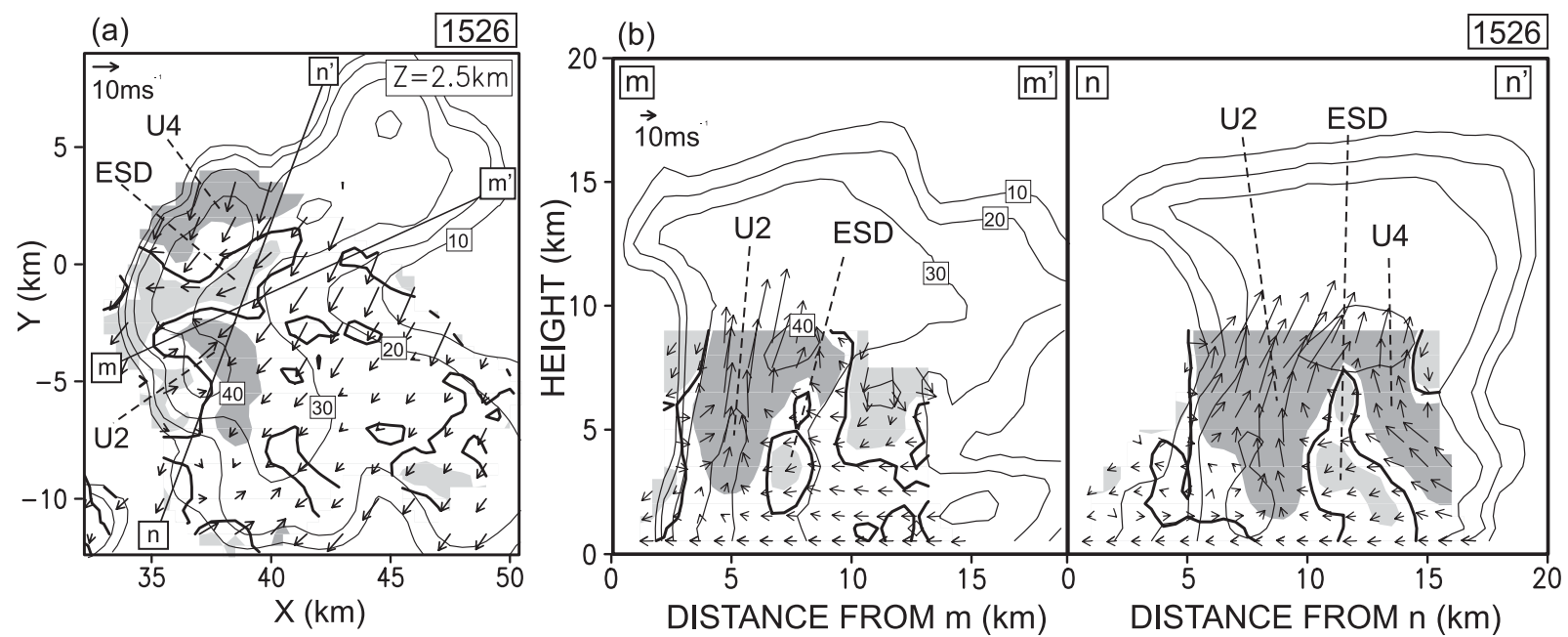

Fig. 16. (a) Horizontal and (b) vertical sections of cell-relative wind and echo field at 1526 LST. The shaded regions and thick solid contours of vertical velocities are the same as in Fig. 10. The contours of radar-echo intensity are 10, 20, 30, and $40 \mathrm{dBZ}$ from the outside.

onto a north-south vertical plane, which is nearly parallel to the ambient low-level vertical wind shear. Downshear-tilting of U2 and upshear-tilting of U4 are clearly presented in the section. The ESD is shown between these updrafts. The single echo core in the SER at middle and upper levels is also depicted. Updrafts U2 and U4 were observed in the upshear and downshear parts of the SER at middle levels. The low-level air from the northern (downshear) side, coming into updraft U4 was forced upward by the surface outflow from the ESD.

The back wall in Fig. 17 shows the radarecho intensity and air motions in the vertical section A-A', which crosses U2 and the ESD. The A- $\mathrm{A}^{\prime}$ section is nearly along the predominant northeasterly airflow at the low and middle levels. The low-level air coming into updraft U2 from the southwestern (upshear) side was forced upward by the descending northeasterly airflow.

The single intense echo region observed between the two updrafts U2 and U4 implies that a large part of the precipitation particles, which grew in these updrafts, were mixed at the middle and upper levels. In short, one large intense radar-echo region in the mature stage was formed in association with two adjacent vigorous updrafts (U2 and U4), which tilted to the downshear and upshear sides in the up- shear and downshear parts of the cloud, respectively.

\section{Discussion}

As presented in Sections 4 and 5, the longlived multicellular cumulonimbus cloud C showed exceptionally deep development among many cumulonimbus clouds on that day. The structure and evolution of the convective cells within the cumulonimbus cloud showed similarities to, and differences from, those within a typical organized multicellular cloud which shows regular and periodic formation of new convective cells on a preferred flank of the cloud. In Section 6.1, the evolution of convective cells comprising the cumulonimbus cloud in Period 1, and the important processes in the formation of the mature stage structure, are compared with a typically organized multicellular cloud. Section 6.2 contains a discussion of how the structures of the convective cells in the mature stage were favorable for the vigorous development of the cumulonimbus cloud.

\subsection{Evolution of the convective cells in Period 1}

The conceptual model of the evolution of the convective cells within cumulonimbus cloud $\mathrm{C}$ during Period 1 is shown in Fig. 18. The developing stage is represented by 3 stages. Stage 1 is based on the observational data at 1444 LST; 


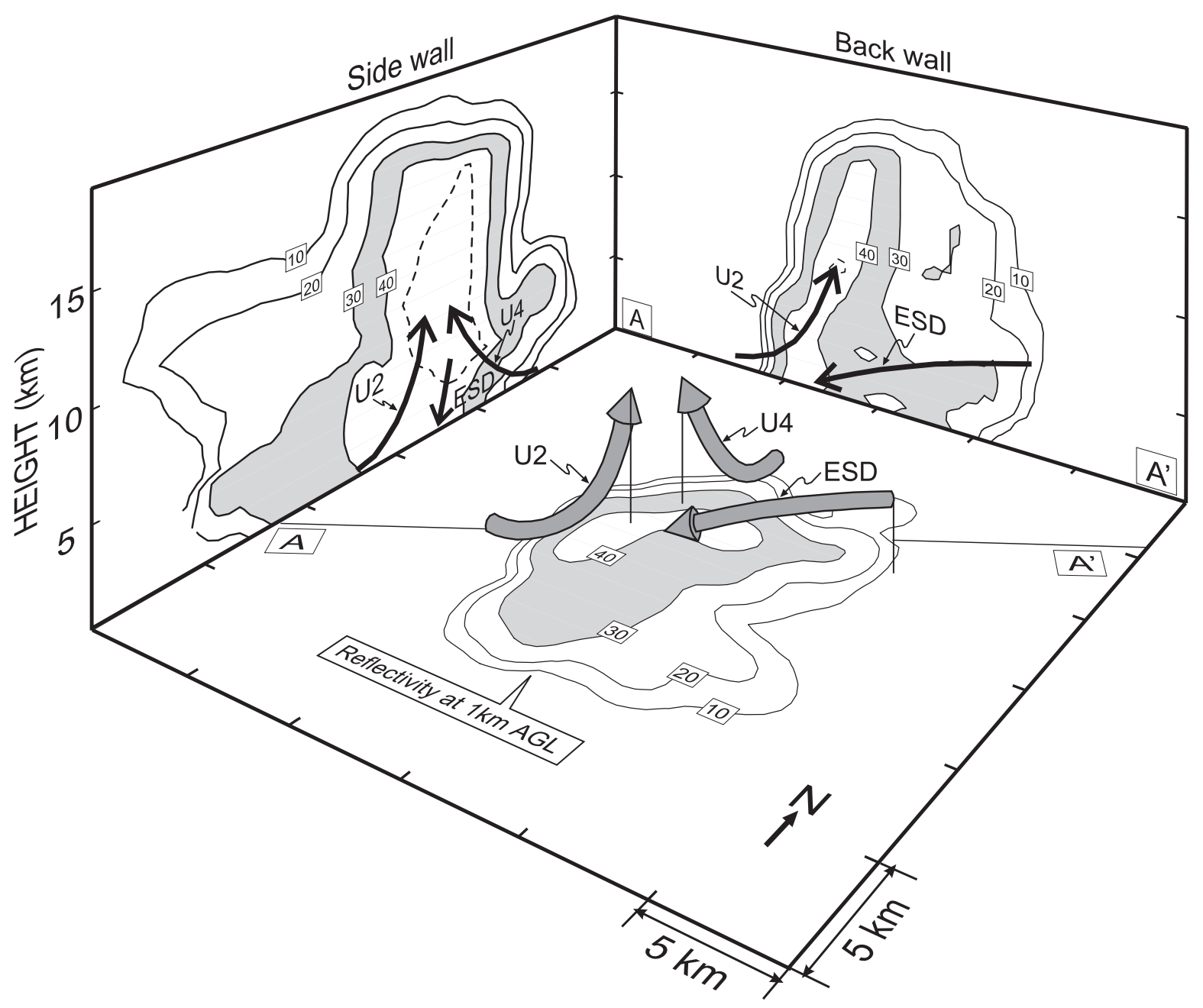

Fig. 17. Schematic structure of the cumulonimbus cloud in the mature stage. The center illustration indicates a three-dimensional model of the significant air motions in the low and middle levels within the cloud (arrows) and radar-echo intensity at $1 \mathrm{~km}$ AGL. The contours of radar-echo intensity are 10, 20, 30, and $40 \mathrm{dBZ}$ from the outside. Areas from 30 to $40 \mathrm{dBZ}$ are shaded. The side wall shows the projection of maximum radar-echo intensity and the air motion onto the northsouth vertical plane. The back wall shows the radar-echo intensity and the vertical motion in the vertical section $\mathrm{A}-\mathrm{A}^{\prime}$.

Stage 2, at both 1451 and 1458 LST; and Stage 3 , at 1505 LST. The feature of the mature stage is based on the data at 1519 LST.

Generally, in the case of an organized multicellular cumulonimbus cloud, low-level strong horizontal convergence occurs in the downshear region of the cloud, and a new updraft is triggered in that region (e.g., Weisman and Klemp 1982). The old updraft weakens and dissipates, because the supply of low-level warm and moist inflow from the downshear side is cut off. One of the similarities of the present cloud to the organized multicellular cloud is that some new cellular echoes form on the downshear side of the cloud (such as cellular echo C4 at Stage 2). A singular aspect of the present cloud is the persistence of cellular echo C2 during Period 1. In Stage 1, cellular echo C3, which was already occupied by the downdraft, was found on the downshear side of cellular echo C2. Cellular echo C4, which had subtstantial updraft (U4), was observed on the downshear side of cellular 
(a)

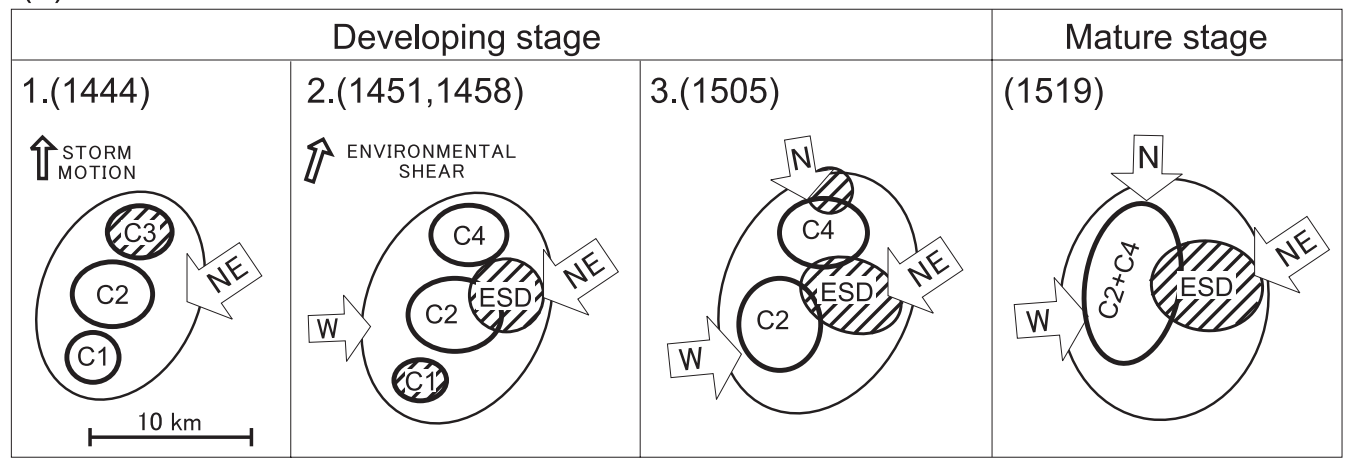

(b)

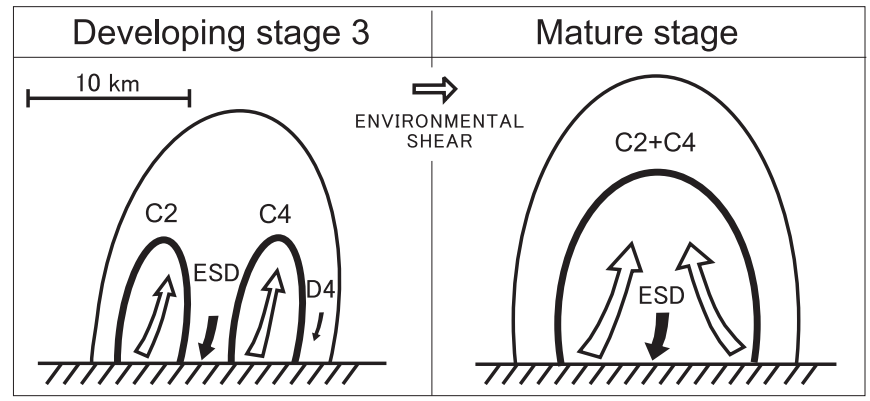

Fig. 18. Conceptual model of the evolution of convective cells within cumulonimbus cloud $\mathrm{C}$ during Period 1. Thin and bold ellipses depict a cumulonimbus cloud and convective cells, respectively. Convective cells are illustrated based on cellular echoes. (a) Horizontal plane representing the structures at the low and middle levels. Large arrows indicate northerly, westerly, and northeasterly cell-relative inflows at the low levels. Substantial downdraft regions are hatched. (b) Vertical plane representing the structures along the direction of vertical shear. The white and black arrows indicate significant updrafts and downdrafts, respectively.

echo C2 in Stages 2 and 3. However, cellular echo $\mathrm{C} 2$ and its updraft U2 persisted during Period 1.

The low-level westerly airflow coming into updraft U2 was continuously forced upward by the descending northeasterly airflow. From Stage 2, the eastern side notch (ESN) became obvious in the region of the northeasterly wind, and coexisted with the ESD after Stage 3. These facts and the existence of a layer dryer than $40 \%$ around $3 \mathrm{~km}$ level (Fig. 3) suggest that the northeasterly wind brought potentially cold environmental air into the eastern portion of cumulonimbus cloud $\mathrm{C}$ at the low and middle levels, and that the ESD developed and was maintained by the evaporation cooling of raindrops in the region of northeasterly wind.

The northeasterly wind relative to the cell motion had already existed around the cumu- lonimbus cloud when the convective echo first appeared. Therefore, the northeasterly wind was not caused by the development of the convective cells in the cumulonimbus cloud, but existed as an external forcing for the cloud. However, sounding data at Fuyang and Nanjing did not show the northeasterly wind relative to the cell motion from the low to middle levels at 1400 LST (Fig. 4). The surface weather map (Fig. 2) indicates that the northeasterly wind relative to the cell motion was not a synoptic-scale disturbance. Several numerical and observational studies showed that local airflows that influenced the evolution and development of cumulonimbus clouds were due to adjacent precipitating clouds (e.g., Misumi et al. 1994; and Geng et al. 1997). In the present case, however, it could not be confirmed whether the cell-relative northeasterly wind was pro- 
duced locally by adjacent precipitating clouds, or whether a small-scale disturbance, which was undetectable at upper-air sounding stations, existed.

It should be noted that cellular echo $\mathrm{C} 4$ also persisted to the mature stage without any formation of a new cellular echo on its downshear side. The change of the inclination of updraft U4 from downshear-tilting in Stage 3 to upshear-tilting in the mature stage (Fig. 18b) is critical for the persistence of updraft $\mathrm{U} 4$, because this change is associated with the intensification of downdraft on the upshear side of $\mathrm{U} 4$, and the dissipation of the downdraft on the downshear side. The change of the inclination of U4 to upshear-tilting was believed to have occurred before the downdraft on the downshear side of U4 completely cut off the supply of environmental low-level warm and moist air coming into updraft U4 from the downshear (north) side. For the formation of an upsheartilting updraft, the updraft root must move toward the downshear side faster than the rising air parcels. The critical speed is smaller when the ambient vertical wind shear is weaker, as discussed by Misumi et al. (1994). We infer that the ESD, and its associated surface outflow from the upshear side of updraft U4, moved the root of U4 to the downshear side and made updraft $\mathrm{U} 4$ tilt to the upshear side in the present case.

\subsection{Structures of the convective cells in the mature stage}

In the mature stage, one large intense radarecho region was formed in association with two adjacent vigorous updrafts (U2 and U4), which tilted to the downshear and upshear sides in the upshear and downshear parts of the cloud, respectively. The echo core of $\mathrm{C} 4$ was located immediately to the south of U4 at $2.5 \mathrm{~km}$ AGL (Fig. 14e), and was occupied by the ESD at $1 \mathrm{~km}$ AGL (Fig. 14d). This fact suggests that the precipitation formed in U4 with upshear tilting began to fall to the upshear side of U4 at the low level. The loading effect of the precipitation would have been favorable for the intensification and persistence of the ESD which was located on the upshear side of U4. The ESD and its surface outflow did not cut off the supply of environmental low-level warm and moist air coming into updraft $\mathrm{U} 4$ from the downshear (north) side. Furthermore, the intensification and persistence of the ESD were favorable to strengthen and maintain the lowlevel convergence at the foot of U2 in the upshear side of the cloud. It can be said that the development of upshear-tilting updraft U4 is favorable for the development of updraft U2. The coexistence of the ESD with two updrafts (U2 and U4) was also favorable for the development of these updrafts, because it reduces the consumption of convective energy by dry compensating downward motions. Thus, the structure of these two adjacent convective cells in the mature stage was favorable for their simultaneous deep developments.

Generally, strong vertical wind shear is considered to be a necessary condition for the development of organized convective clouds (e.g., Weisman and Klemp 1982), while it tends to inhibit cumulus convection. In the present case, the environmental condition of weak vertical wind shear allowed the low-level inflow coming into the cloud from the upshear (southwest) side, in addition to that from the downshear (north) side, under the existence of local low- to mid-level northeasterly wind. A weak vertical shear condition did not inhibit the vigorous development of the present cloud. Consequently, deep developments of two adjacent convective cells resulted in the rapid and vigorous development of the cumulonimbus cloud in the mature stage.

\section{Summary}

A multicellular cumulonimbus cloud developed exceptionally over the Huaihe River Basin in China on 13 July 1998, during the GAME/ HUBEX. It had a lifetime longer than 3.5 hours and a maximum echo-top height of $19 \mathrm{~km}$ AGL under an atmospheric condition characterized by large CAPE (2300 $\mathrm{J} \mathrm{kg}^{-1}$ ) and weak vertical wind shear $\left(1.6 \mathrm{~m} \mathrm{~s}^{-1} \mathrm{~km}^{-1}\right.$ toward the northnortheast below $5 \mathrm{~km}$ AGL). In this paper, the detailed structure and evolution of deeply developed convective cells, within the long-lived multicellular cumulonimbus cloud during the period from its early development to its mature stage, have been described, mainly using the observational data of Doppler radars.

During the analysis period, the mean motion of convective cells within the cloud was about $7.0 \mathrm{~m} \mathrm{~s}^{-1}$ toward the north. The ambient wind 
directions relative to the convective cells were northerly to westerly at the low levels (Fig. 4). New convective cells tended to form on the downshear side of the cloud. However, several singularities were shown in the evolution of the convective cells in the present cloud compared with that in a so-called organized multicellular cumulonimbus cloud.

In the developing stage, the convective cell (C2) developed remarkably around the center of the cumulonimbus cloud. It persisted even after a new convective cell (C4) developed on its downshear side. The northeasterly wind relative to the cell motion continuously came into the eastern side of the cloud at the low and middle levels, although it was not observed in the synoptic scale environment. The downdraft (ESD) appeared in the eastern side of the cloud, and coexisted with the echo notch (ESN). It is inferred that the northeasterly wind brought potentially cold environmental air into the eastern side of the cloud at the low and middle levels, and the ESD was maintained by the evaporation cooling of raindrops in the northeasterly wind. The descending northeasterly airflow continuously lifted the low-level westerly airflow into the updraft (U2) of convective cell $\mathrm{C} 2$.

In the mature stage, a single large strong echo region above $40 \mathrm{dBZ}$ (SER) was observed, with vigorous development of two adjacent convective cells, $\mathrm{C} 2$ and $\mathrm{C} 4$, in the upshear and downshear parts of the cloud, respectively. The SER had a single echo core at the middle and upper levels, while two echo cores were distinguishable at the low levels. The SER was nearly upright, and its horizontal area was almost the same between 5 and $15 \mathrm{~km}$ AGL, with a diameter of about $7 \mathrm{~km}$. The ESN was observed widely at the low and middle levels, and was contiguous to the eastern side of the SER. The upshear-side updraft (U2) tilted to the downshear side. The downshear-side updraft (U4) tilted to the upshear side, although it tilted to the downshear side in the developing stage. The ESD developed between them and coexisted with the ESN in the region of northeasterly wind. Below updraft U2, descending northeasterly airflow continuously lifted the low-level air from the upshear (southwestern) side of the cloud. The ESD, and its surface outflow, did not cut off the supply of low-level air coming into updraft U4 from the downshear (northern) side.

The change of inclination of the downshearside updraft U4 from downshear-tilting to upshear-tilting was caused by the surface outflow associated with the ESD on the upshear side of U4. The development of upshear-tilting updraft U4 was associated with the intensification and persistence of the ESD, which was favorable to strengthen low-level convergence at the foot of U2 in the upshear side of the cloud. Consequently, these two adjacent convective cells (C2 and $\mathrm{C} 4)$ resulted in the rapid and vigorous development of a cumulonimbus cloud under the condition of weak vertical wind shear.

\section{Acknowledgments}

We would thank Professor H. Uyeda, Nagoya University, for his useful review of a draft of this paper. We are most grateful to the Chinese GAME/HUBEX Project Office for providing the data of upper-air sounding. Thanks are also extended to all members of the GAME/HUBEX project for their help and cooperation in the observations. We are also grateful to staff members of Shouxian and Fengtai Meteorological Observatories and Huainan Chaoyang Hospital for their cooperation and kind support in the observation. We thank Dr. M. Murakami and anonymous reviewers for their helpful comments. This work was supported by a Grant-inAid for Scientific Research from the Ministry of Education, Science, Culture, and Sports of Japan. This study is a part of the results of the GAME/HUBEX.

\section{References}

Bluestein, H.B. and S.S. Parker, 1993: Modes of isolated severe convective storm formation along the dryline. Mon. Wea. Rev., 121, 1354-1372.

Cressman, G.P., 1959: An operational objective analysis system. Mon. Wea. Rev., 87, 367-374.

Droegemeier, K.K. and R.B. Wilhelmson, 1985a: Three-dimensional numerical modeling of convection produced by interacting thunderstorm outflows. Part I: Control simulation and lowlevel moisture variations. J. Atmos. Sci., 42, 2381-2403.

and $-1985 \mathrm{~b}$ : Three-dimensional numerical modeling of convection produced by interacting thunderstorm outflows. Part II: Variation in vertical wind shear. J. Atmos. Sci., 42, 2404-2414. 
Fujiyoshi, Y. and B. Geng, 1995: Dual Doppler radar observation of a tropical rainband developed from two convective clouds. J. Meteor. Soc. Japan, 73, 471-490.

Gal-Chen, T., 1982: Errors in fixed and moving frame of references: Applications for conventional and Doppler radar analysis. J. Atmos. Sci., 39, 2279-2300.

Geng, B., Y. Fujiyoshi, and T. Takeda, 1997: Evolution of a multicell thunderstorm in association with mid-level rear inflow enhanced by a midlevel vortex in an adjacent thunderstorm. $J$. Meteor. Soc. Japan, 75, 619-637.

Jones, D.M.A., 1956: Rainfall drop-size distribution and radar reflectivity. Res. Rept. No. 6. Urbana: Meteor. Lab., Illinois State Water Survey.

Kato, K., J. Matsumoto, and H. Iwasaki, 1995: Diurnal variation of $\mathrm{Cb}$-clusters over China and its relation to large-scale conditions in the summer of 1979. J. Meteor. Soc. Japan, 73, 12191234.

Klemp, J.B. and R.B. Wilhelmson, 1978a: The simulation of three-dimensional convective storm dynamics. J. Atmos. Sci., 35, 1070-1096.

and - 1978b: Simulations of right- and left-moving storms produced through storm splitting. J. Atmos. Sci., 35, 1097-1110.

Misumi, R., M. Divjak, S. Tanahashi, and T. Takeda, 1994: A numerical study on the formation of organized convective storms: Part I. Formation patterns of long-lasting cells. J. Atmos. Sci., 72, 235-253.

Shinoda, T. and H. Uyeda, 2002: Effective factors in the development of deep convective clouds over the wet region of eastern China during the summer monsoon season. J. Meteor. Soc. Japan, 80, 1395-1414.

Simpson, J., N.E. Westcott, R.J. Clerman, and R.A. Pielke, 1980: On cumulus mergers. Arch. $\mathrm{Me}$ teor. Geophys. Bioklimatol., A29, 1-40.

Takeda, T. and H. Imai, 1976: On the behavior of long-lasting cellular echoes. J. Meteor. Soc. Japan, 54, 399-406.

Tao, W.-K. and J. Simpson, 1984: Cloud interaction and merging: Numerical simulations. J. Atmos. Sci., 41, 2901-2917.

- and — 1989: A further study of cumulus interactions and mergers: Three-dimensional simulations with trajectory analyses. J. Atmos. Sci., 49, 1826-1847.

Warner, C., J. Simpson, G. van Helvoirt, D.W. Martin, D. Suchman, and G.L. Austin, 1980: Deep convection on day 261 of GATE. Mon. Wea. Rev., 108, 169-194.

Weisman, M.L. and J.B. Klemp, 1982: The dependence of numerically simulated convective storms on vertical wind shear and buoyancy. Mon. Wea. Rev., 110, 504-520.

Wilhelmson, R.B. and J.B. Klemp, 1978: A numerical study of storm splitting that leads to long-lived storms. J. Atmos. Sci., 35, 1974-1986. 